\title{
The influence of the 2006 Indonesian biomass burning aerosols on tropical dynamics studied with the GEOS-5 AGCM
}

Journal article: Journal of Geophysical Research, Atmospheres

Author list:

Lesley E. Ott Lesley.E.Ott@nasa.gov

Bryan Duncan $\quad$ Bryan.N.Duncan@nasa.gov

Steven Pawson $\quad$ Steven.Pawson-1@nasa.gov

Peter Colarco Peter.R.Colarco@nasa.gov

Mian Chin_ Mian.Chin@nasa.gov

Cynthia Randles Cynthia.A.Randles.1@gsfc.nasa.gov

Thomas Diehl Thomas.L.Diehl@nasa.gov

Eric Nielsen Jon.E.Nielsen@nasa.gov

Abstract:

The direct and semi-direct effects of aerosols produced by Indonesian biomass burning (BB) during August-November 2006 on tropical dynamics have been examined using NASA's Goddard Earth Observing System, Version 5 (GEOS-5) atmospheric general circulation model (AGCM). The AGCM includes $\mathrm{CO}$, which is transported by resolved and sub-grid processes and subject to a linearized chemical loss rate.

Simulations were driven by two sets of aerosol forcing fields calculated offline, one that included Indonesian BB aerosol emissions and one that did not. In order to separate the influence of the aerosols from internal model variability, the means of two ten-member ensembles were compared. 
Diabatic heating from BB aerosols increased temperatures over Indonesia between 150 and $400 \mathrm{hPa}$. The higher temperatures resulted in strong increases in upward grid-scale vertical motion, which increased water vapor and CO over Indonesia. In October, the largest increases in water vapor were found in the mid-troposphere $(\sim 25 \%)$ while the largest increases in CO occurred just below the tropopause ( $80 \mathrm{ppbv}$ or $\sim 50 \%$ ). Diabatic heating from the Indonesian BB aerosols caused CO to increase by $9 \%$ throughout the tropical tropopause layer in November and 5\% in the lower stratosphere in December. The results demonstrate that aerosol heating plays an important role in the transport of $\mathrm{BB}$ pollution and troposphere-to-stratosphere transport. Changes in vertical motion and cloudiness induced by aerosol heating can also alter the transport and phase of water vapor in the upper troposphere/lower stratosphere.

\section{Popular Summary:}

Every year, large quantities of gases and particles (known as aerosols) are released into the atmosphere by fires. In Indonesia, fires are often set deliberately to convert swamp forests to agricultural land. During El Niño episodes, drought conditions in Indonesia allow these fires to spread out of control, consuming large amounts of carbon-rich peat deposits beneath the forests. An Indonesian fire outbreak that occurred between August and November 1997 was estimated to release approximately one third as much carbon monoxide as is released annually from fossil fuel combustion worldwide. Aerosols produced by the fires have been shown in previous studies to strongly influence the transmission of radiation in the region, cooling Earth's surface and the top of the atmosphere while warming the atmosphere itself. 
A similar, though smaller, fire outbreak occurred in Indonesia in 2006. In this study, we use NASA's Goddard Earth Observing System, Version 5 (GEOS-5) atmospheric general circulation model to study the impact of aerosols produced by the 2006 Indonesian fires on atmospheric temperature, moisture, and circulation in the region. The influence of aerosols was identified by conducting two sets of simulations, one set which included the effects of aerosols produced by the Indonesian fires and one set that did not, and comparing the results. This analysis shows that aerosols produced by the 2006 fires increased temperatures over Indonesia with the greatest increases occurring during October and November between 7.5 and $14 \mathrm{~km}$ above the surface. Because warmer air tends to be more buoyant, increases in temperature caused by aerosols strengthen upward motion over Indonesia. Changes in vertical motion are accompanied by changes in horizontal winds. When Indonesian aerosols are present, winds converge over Indonesia at low levels and diverge at upper levels. The aerosol induced changes in vertical and horizontal winds alter the distribution of trace gases, such as water vapor and carbon monoxide, in the region. The amount of water vapor in the atmosphere increases by as much as $25 \%$ at $7.5 \mathrm{~km}$ elevation. Peak increases in carbon monoxide are found just below the tropopause, the boundary between the troposphere and the stratosphere, and can be as large as $50 \%$ in October. The results also suggest that aerosol heating can increase the transport of pollution from fires to the lower stratosphere. This research represents a significant contribution to understanding the physical processes that determine the chemistry and composition of the upper troposphere/lower stratosphere region which is critically important in determining Earth's climate. 


\section{The influence of the 2006 Indonesian biomass burning aerosols on tropical dynamics studied with the GEOS-5 AGCM}

Lesley Ott ${ }^{1}$, Bryan Duncan ${ }^{2}$, Steven Pawson ${ }^{3}$, Peter Colarco ${ }^{2}$, Mian Chin ${ }^{2}$, Cynthia Randles ${ }^{1}$, Thomas Diehl ${ }^{1}$, Eric Nielsen ${ }^{4}$

${ }^{1}$ Goddard Earth Sciences and Technology Center, University of Maryland, Baltimore County

${ }^{2}$ NASA Goddard Space Flight Center, Atmospheric Chemistry and Dynamics Branch ${ }^{3}$ NASA Goddard Space Flight Center, Global Modeling and Assimilation Office ${ }^{4}$ Science Systems and Applications, Inc.

Submitted to Journal of Geophysical Research-Atmospheres

September 10, 2009 


\begin{abstract}
The direct and semi-direct effects of aerosols produced by Indonesian biomass burning (BB) during August-November 2006 on tropical dynamics have been examined using NASA's Goddard Earth Observing System, Version 5 (GEOS-5) atmospheric general circulation model (AGCM). The AGCM includes CO, which is transported by resolved and sub-grid processes and subject to a linearized chemical loss rate. Simulations were driven by two sets of aerosol forcing fields calculated offline, one that included Indonesian BB aerosol emissions and one that did not. In order to separate the influence of the aerosols from internal model variability, the means of two ten-member ensembles were compared.
\end{abstract}

Diabatic heating from BB aerosols increased temperatures over Indonesia between 150 and $400 \mathrm{hPa}$. The higher temperatures resulted in strong increases in upward grid-scale vertical motion, which increased water vapor and CO over Indonesia. In October, the largest increases in water vapor were found in the mid-troposphere ( 25\%) while the largest increases in CO occurred just below the tropopause ( $80 \mathrm{ppbv}$ or 50\%). Diabatic heating from the Indonesian BB aerosols caused CO to increase by $9 \%$ throughout the tropical tropopause layer in November and $5 \%$ in the lower stratosphere in December. The results demonstrate that aerosol heating plays an important role in the transport of BB pollution and troposphere-to-stratosphere transport. Changes in vertical motion and cloudiness induced by aerosol heating can also alter the transport and phase of water vapor in the upper troposphere/lower stratosphere. 


\section{Introduction}

The black and organic carbon aerosols from forest and agricultural fires can have significant impacts on radiative forcing, atmospheric composition, and atmospheric dynamics, especially for fires with high biomass loadings. Tropical peatlands in Indonesia store large amounts of carbon ( $55 \pm 10 \mathrm{Gt}$ of Carbon; Jaenicke et al., 2008). Intact peatlands support swamp forests overlying peat deposits which extend up to $20 \mathrm{~m}$ in depth but conversion for agricultural land use has resulted in the burning of large areas of peatlands (Page et al, 2002). In drought conditions brought on by El Niño (e.g. van der Werf et al., 2003; Wang et al., 2004; Logan et al., 2008) or the Indian Ocean Dipole (Field et al., 2009), deliberately set fires can spread out of control, consuming underlying peat deposits in addition to above ground forest biomass and resulting in large fluxes of carbon to the atmosphere.

During one of the largest burning events of the Twentieth Century, the Indonesian wildfires of 1997 (August-November), the aerosol radiative forcing at the surface was estimated to be -10 to $-50 \mathrm{~W} / \mathrm{m}^{2}$ over the ocean near Indonesia, -5 to $-50 \mathrm{~W} / \mathrm{m}^{2}$ over the central Indian Ocean, and as low as $-150 \mathrm{~W} / \mathrm{m}^{2}$ over the land where burning occurred (Duncan et al., 2003; Podgorny et al., 2003). Duncan et al. [2007a] used the Global Modeling Initiative (GMI) chemical transport model (CTM) to estimate that these fires increased CO in the tropical tropopause layer (TTL) by more than $40 \%$ and lower stratosphere (LS) by more than $10 \%$ for several months. Their results also demonstrated that the increased presence of $\mathrm{CO}$ resulting from the Indonesian wildfires could reduce 
$\mathrm{OH}$ mixing ratios, increasing atmospheric lifetimes and troposphere-to-stratosphere transport of trace gases.

Another, smaller, wildfire outbreak occurred from August to November 2006 and is the focus of this study. Logan et al. [2008] used data from the Tropospheric Emissions Spectrometer (TES) to assess differences in $\mathrm{O}_{3}, \mathrm{CO}$, and water vapor between 2005 and 2006. Their results indicated that CO mixing ratios at $511 \mathrm{hPa}$ were more than $80 \mathrm{ppbv}$ greater in October and November of 2006 relative to the same months in 2005 over the Indonesian region; ozone mixing ratios were $15-30 \mathrm{ppbv}$ (30-75\%) larger. Ziemke et al. [2009] used satellite observations and the GMI model to estimate that BB increased tropospheric ozone mixing ratios in the Indonesian region by 15-25\% during the 2006 event. Chandra et al. [2009] used the GMI model to separate the dynamical impact of the $2006 \mathrm{El}$ Niño from changes in BB emissions. They found that emissions and dynamical changes contributed almost equally to observed ozone increases over Indonesia in October and November, though changes due to emissions were focused in the Indonesian region while dynamical changes affected a larger area in the Indian and Pacific Oceans. The global burden of CO increased by 8-12\% from October through December as a result of the 2006 fires (Chandra et al., 2009).

In addition to modifying atmospheric composition, $\mathrm{BB}$ aerosols alter the atmospheric circulation in several ways. Black carbon (BC) aerosol absorbs incoming solar radiation, while organic carbon (OC) and sulfate aerosol both scatter and absorb (direct effect). These aerosols affect the properties and lifetimes of clouds by modifying atmospheric heating rates (semi-direct effect). The aerosol indirect effect refers to the influence of aerosols on cloud formation and optical properties through microphysical 
processes. Ming and Ramaswamy [2009] used the AM2.1 atmospheric general circulation model (AGCM) which includes aerosol direct, semi-direct and indirect effects and found that increasing aerosols from preindustrial to 1990 levels caused a decrease in the global annual mean surface temperature of $1.9 \mathrm{~K}$. While cooling the troposphere, the increase in aerosols typically warmed the stratosphere. Menon et al. [2002] and Randles and Ramaswamy [2008] found that absorbing carbonaceous aerosol associated with the “Atmospheric Brown Cloud” (Ramanathan and Crutzen, 2003) over Asia increases diabatic heating and contributes to enhanced upward motion, a strengthening of the monsoon circulation, and increased precipitation in parts of Asia during the pre-monsoon period, a mechanism referred to as the "Elevated Heat Pump" (Lau et al., 2006, Lau and Kim, 2006). Increased diabatic heating associated with aerosols may also induce convection and lead to cloud formation, which contributes to the surface solar flux reduction (Rudich et al., 2003; Randles and Ramaswamy, 2008). Reduction in solar flux to the surface due to aerosols and clouds weakens the north-south temperature gradient, which ultimately leads to a weakening of the monsoon (Chung and Ramanathan, 2006). Rajeev et al. [2008] studied the impact of the 1997 Indonesia wildfires on sea surface temperature (SST) using satellite observations of aerosol optical depth, SST, and a radiative transfer model. They found that aerosol cooling resulted in a 1 to $2^{\circ} \mathrm{C}$ negative SST anomaly in the eastern equatorial Indian Ocean though the impact likely would have been larger had decreased cloud cover during this period not resulted in a positive anomaly in net cloud radiative forcing. The decrease in SSTs resulting from BB aerosols may have contributed to a strengthening of the Indian Ocean Dipole. 
In this study, we examine the impact of the direct and semi-direct effects of sulfate and carbonaceous aerosols from the 2006 Indonesian fires on tropical dynamics using the Goddard Earth Observing Systsem, Version 5 (GEOS-5) AGCM. Simulations that do and do not include the radiative effects of these aerosols are compared in order to estimate changes to horizontal and vertical transport, temperature, water vapor, and $\mathrm{CO}$ mixing ratios in the Indonesian region. An ensemble methodology is used to separate the role of aerosol forcing from the potentially chaotic response of the model to perturbations. Ten-member ensembles with and without Indonesian aerosols were produced by initializing simulations with meteorological fields taken from different days in April, 2006. Section 2 includes details on the GEOS-5 AGCM while Section 3 describes the methodology used in this study. Section 4 presents results from the ensemble simulations and Section 5 includes a summary and conclusions.

\section{GEOS-5 AGCM description}

The GEOS-5 AGCM is a central component of the GEOS- 5 atmospheric data assimilation system (Rienecker et al., 2008), where it is used for meteorological analysis and forecasting (Zhu and Gelaro, 2008). By adding trace gases and aerosol modules, GEOS-5 has also been developed as a tool for studying atmospheric composition and climate. Ott et al. [2009] used ensemble simulations of GEOS-5 to quantify the impact of changes in the model's moist physics code on global CO distributions.

The AGCM combines a finite volume dynamical core [Lin, 2004] with a column physics package and the land-surface model of Koster et al. [2000]. The model domain extends from the surface to $0.01 \mathrm{hPa}$ and uses 72 hybrid sigma-P layers that transition 
from terrain-following near the surface to pure pressure levels above $180 \mathrm{hPa}$. In this study, the AGCM was used with a horizontal resolution of $1^{\circ}$ by $1.25^{\circ}$ (latitude by longitude). Physics computations are performed every 30 minutes.

The column physics model contains several components. Boundary-layer turbulence is represented using the Lock et al. [2000] scheme. Moist processes in GEOS-5 are represented by a convective parameterization and a prognostic cloud scheme. Convection is parameterized using the relaxed Arakawa-Schubert (RAS) scheme of Moorthi and Suarez [1992], a modified version of the Arakawa-Schubert scheme (Arakawa and Schubert, 1974), in which the atmosphere is relaxed towards equilibrium. The prognostic cloud scheme contained in GEOS-5 calculates large-scale ice and liquid condensate by assuming a probability distribution function (pdf) of total water. Condensate is removed from the domain by evaporation, auto-conversion of liquid condensate, sedimentation of frozen condensate, and accretion of condensate by falling precipitation. Radiation transfer is computed using the parameterization of Chou and Suarez [1994, 2002] and Chou et al. [2003]. The model accounts for the radiative effects of sulfate, dust, sea-salt, organic carbon and black carbon aerosol. For this study, two different three-dimensional aerosol distributions were specified in the AGCM.

The GEOS-5 AGCM has been adapted to include several atmospheric chemistry modules: this study uses a version with a simple representation of $\mathrm{CO}$. Emissions of $\mathrm{CO}$ follow Duncan et al. [2007a] and Duncan and Logan [2008]. Relevant to this study, CO emissions from biofuels follow the Yevich and Logan [2003] inventory while BB emissions follow the Global Fire Emissions Database, version 2 (GFEDv2) inventory (van der Werf et al., 2006). All simulations include BB emissions of CO from Indonesia 
to isolate the effects of aerosol heating on trace gas distributions. In this study, we use a CO-only simulation similar to the one described in Duncan et al. [2007b], which we briefly describe here. CO emissions from fossil fuels, biofuels, and BB are increased by $20 \%, 19 \%$, and $11 \%$, respectively, in order to account for CO production from nonmethane hydrocarbons emitted from these sources. Isoprene and monoterpene emissions were calculated by the GMI combined troposphere-stratosphere CTM using the method of Guenther et al. [1995] and are released directly as CO after applying an estimated yield during the oxidation of these species. Monthly mean methane fields are used to calculate CO produced by methane oxidation as described in Bian et al. [2007]. In order to calculate $\mathrm{CO}$ loss through reaction with $\mathrm{OH}$, monthly mean $\mathrm{OH}$ fields produced by the GMI CTM for the year 2006 are used along with a prescribed loss frequency for CO.

Figure 1 shows a comparison of $\mathrm{CO}$, a tracer of transport and fire pollution, in the upper troposphere (UT) as observed by the Microwave Limb Sounder (MLS, version 2/level 2; Livesey et al., 2008) instrument onboard the NASA Aura satellite and modeled by GEOS-5. Though this MLS data product is known to be biased high at $215.4 \mathrm{hPa}$ (Livesey et al., 2008), it has been used previously to qualitatively validate simulated CO distributions (e.g. Duncan et al., 2007a). The model captures the main features of transport to and within the UT that are evident in the observations. The long-range transport pathways of the pollution from the 1997 Indonesian fires are detailed in Duncan et al. [2003] and Duncan et al. [2007a]; these pathways are similar to those of the 2006 event. Areas of monsoonal convection near the main burning regions in Africa, South America and Indonesia loft fire pollutants to the UT where they are transported by the prevailing tropical easterlies. Some of the pollution is peeled away by the subtropical 
jets, moving rapidly eastward and circling the globe. This feature is best seen over the Pacific Ocean in Figure 1. To our knowledge, these MLS CO measurements are the first satellite observations to show this long-range transport of fire pollution within the subtropical jets.

\section{Methodology}

This section describes two important aspects of the experimental design: the construction of the aerosol distributions specified in GEOS- 5 and the use of ensembles of GEOS-5 simulations to separate physical signals from statistical variations.

\subsection{Aerosol Distributions}

By using specified aerosol fields to force GEOS-5, we are able to isolate the radiative impacts of aerosols on dynamics without considering the complex feedbacks of dynamics on aerosol distributions. This could include alteration of horizontal and vertical advection, removal by precipitation, and transport in convective updrafts. Aerosol indirect effects are also neglected in this study.

Two aerosol distributions, including and excluding the impacts of the Indonesian BB emissions, were constructed for the GEOS-5 AGCM experiments. They were computed from runs made with Goddard Chemistry Aerosol Radiation and Transport (GOCART) model (Chin et al., 2002) driven by meteorological analyses from the GEOS-4 data assimilation system for 2006. BC and OC aerosol emissions from fires were specified according to the GFEDv2 inventory (van der Werf et al., 2006). Yu et al. [2009] compared the vertical distribution of GOCART calculated aerosols during this period with observations obtained by Cloud-Aerosol Lidar and Infrared Pathfinder Satellite Observations (CALIPSO). Seasonal mean aerosol optical depth (AOD) from 
GOCART for SON 2006 compared well with CALIPSO observations in the Indonesian region, though both CALIPSO and GOCART AOD were lower than AOD from the MODerate Imaging Spectroradiometer (MODIS). A comparison of seasonal-mean aerosol scale heights calculated from CALIPSO and GOCART suggests that GOCART consistently overestimates the aerosol scale height relative to CALIPSO although in the Indonesian region, these differences are less than $0.5 \mathrm{~km}$.

Two GOCART model integrations were performed to produce the aerosol forcing fields used by GEOS-5. One simulation (AERO) included all BB emissions specified by the GFEDv2 inventory for $\mathrm{BC}, \mathrm{OC}$, and $\mathrm{SO}_{2}$ while the second simulation (NAERO) was identical, expect that it omitted those sources contained in Indonesian land grid boxes. Both simulations were driven with identical GEOS-4 DAS meteorological fields for 2006. Figure 2 shows the difference in column aerosol loading between the two sets of aerosol fields for BC, OC, and sulfate during October. For sulfate aerosol, the absence of Indonesian emissions is noticeable primarily over Indonesia. BC and OC aerosols from Indonesia affect a larger region with high aerosol loadings extending thousands of kilometers into the Pacific and Indian Oceans.

Figure 3 shows the mean vertical distribution during SON 2006 and annual cycle of total aerosol mass in the Indonesian region $\left(100^{\circ}\right.$ to $120^{\circ} \mathrm{E}$ and $10^{\circ} \mathrm{S}$ to $\left.10^{\circ} \mathrm{N}\right)$. $\mathrm{OC}$ dominates the aerosols emitted from the fires with the greatest concentrations found near the surface. Thampi et al. [2009] analyzed CALIPSO observations of the 2006 Indonesian smoke plume and found that the majority of aerosols remained below $3 \mathrm{~km}$ which is consistent with the vertical distribution calculated by GOCART. Though mixing ratios are much smaller than at low levels, significant amounts of aerosol are 
present in the mid- and upper troposphere. Total aerosol mass in the region begins to increase in August with peaks in October and early November.

\subsection{GEOS-5 Ensembles}

It is necessary to use an experimental strategy that can isolate significant impacts of $\mathrm{BB}$ aerosols on the circulation, in the sense that the impact of the aerosol forcing is larger than the "natural variability" of the atmosphere. For this study, this has been achieved using ensembles of simulations.

The AERO and NAERO aerosol fields produced by GOCART were used to force two ten-member ensembles of GEOS-5 AGCM simulations. Aerosol distributions were read in daily and interpolated to the 30-minute model time step. Simulations in each ensemble were initialized using meteorological fields from April 1, 3, 5, 7, 9, 11, 13, 15, 17 , and 19 in order to introduce variability. Nine-month model integrations began in April, 2006 to allow the impact of the difference in initial condition to develop prior to the period of burning (August through November) and ended in December, 2006. The AGCM was run in climate mode in which Reynolds analyzed SSTs (Reynolds et al., 2007) are prescribed but no atmospheric data are assimilated. Even without data assimilation, the strong control exerted by the SST anomalies on the atmosphere means that simulations are able to capture the major transport features of the 2006 El Niño in the tropical atmosphere.

It is important to note that because observed SSTs were used as input to the model, the ensemble of simulations in which the Indonesian aerosol source was removed cannot be considered to be without the influence of these aerosols. Rajeev et al. [2008] analyzed observed SSTs to estimate that aerosol cooling associated with the 1997 
Indonesian wildfires decreased SSTs in parts of the Indian Ocean $1-2^{\circ} \mathrm{C}$ though the impact would likely have been greater if changes in cloud cover had not also occurred.

A number of studies have demonstrated the importance of ensemble size in separating responses of the climate system to perturbations from internal model variability or "noise" (e.g. Taschetto and England, 2008; Wehner, 2000). In order to separate differences between the AERO and NAERO ensembles caused by Indonesian aerosols from noise, we use the Student's t-test statistic which takes into account the means and standard deviations of both ensembles. The Student's t-test has frequently been used to determine the significance of differences between ensembles of GCM simulations (e.g. Vitart et al., 1997; Li, 1999; Huebener et al., 2007; Hargreaves et al., 2007). In this study, differences are considered significant if they meet or exceed the 95\% confidence level. To calculate profiles of changes induced by aerosols, we calculate the area mean change in a variable including all grid cells from $100^{\circ}$ to $120^{\circ} \mathrm{E}$ and from $10^{\circ} \mathrm{S}$ to $10^{\circ} \mathrm{N}$. We also calculate this quantity including only those grid cells in which differences are considered statistically significant in the sum but dividing over the same area. This quantity gives an indication of how much of the profile of differences between the AERO and NAERO ensembles can be considered statistically significant; the similarity of the two profiles indicates the relative significance of the changes in the Indonesian region.

\section{4. $\quad$ Results}

\subsection{Radiative forcing}

Figure 4 shows the radiative forcing (change in net irradiance; Ramaswamy et al., 2001) resulting from Indonesian fire aerosols at the surface and top of the atmosphere 
(TOA). The inclusion of aerosols emitted from Indonesia results in direct radiative forcings at the TOA as low as $-30 \mathrm{~W} \mathrm{~m}^{-2}$ over areas of Kalimantan and the Karimata Strait. Areas of direct radiative forcing at the TOA as low as $-6 \mathrm{~W} \mathrm{~m}^{-2}$ extend several thousand kilometers into the Indian Ocean. The change in ensemble mean cloud radiative forcing which results from including the aerosols was also calculated. The presence of Indonesian aerosols tends to increase cloud radiative forcing at the TOA with the largest increases (greater than $10 \mathrm{~W} \mathrm{~m}^{-2}$ ) found in the Indian Ocean to the west of Indonesia. When the cloud and direct aerosol impacts are considered together, the magnitude is typically between 0 and $-10 \mathrm{~W} \mathrm{~m}^{-2}$ over Kalimantan and the Karimata Strait and between 0 and $10 \mathrm{~W} \mathrm{~m}^{-2}$ over the Indian Ocean.

Stronger impacts are seen in the surface energy balance. Direct radiative forcings as low as $-220 \mathrm{~W} \mathrm{~m}^{-2}$ are found over Kalimantan. Over Kalmintan and Sumatra, direct radiative forcings are typically less than $-50 \mathrm{~W} \mathrm{~m}^{-2}$ while large areas of the equatorial Indian and Pacific Oceans are subject to radiative forcings between -5 and -50 $\mathrm{W} \mathrm{m} \mathrm{m}^{-2}$. At the surface, positive cloud radiative forcings exceed $50 \mathrm{~W} \mathrm{~m}^{-2}$ over a small area on Kalimantan. Changes in cloudiness have a smaller but statistically significant impact over parts of the Indian Ocean. When cloud and clear-sky radiative forcings are considered together, peak radiative forcing at the surface is $-160 \mathrm{~W} \mathrm{~m}^{-2}$.

\subsection{Temperature}

Figure 5 shows profiles of the changes in short and long wave heating rates and cloudiness in October caused by the simulation of aerosol direct and semi-direct effects. Heating rate profiles, calculated from $100^{\circ}$ to $120^{\circ} \mathrm{E}$ and $10^{\circ} \mathrm{S}$ to $10^{\circ} \mathrm{N}$, include both cloud and aerosol heating effects. Indonesian BB aerosols result in short wave heating 
throughout the atmosphere with the largest impact (greater than $0.4 \mathrm{~K} \mathrm{day}^{-1}$ ) found at low levels. A secondary peak is found in the UT. The profile of change in long wave radiative heating largely reflects changes in cloudiness. The largest change in cloud cover occurs between 100 and $200 \mathrm{hPa}$. A small but statistically significant increase in cloudiness of $4-5 \%$ is found from 200 to $450 \mathrm{hPa}$ while a slightly larger increase occurs in the layers between 450 and $600 \mathrm{hPa}$. The largest increases in long-wave radiative heating are found below the region of enhanced cloud cover. Between 150 and $500 \mathrm{hPa}$, changes in cloud cover result in long wave cooling with the greatest cooling of $-0.45 \mathrm{~K}$ day $^{-1}$ occurring at approximately $200 \mathrm{hPa}$.

Strong increases in temperature occur in the mid- to upper troposphere between 150 and $400 \mathrm{hPa}$ because of increased diabatic heating caused by Indonesian BB aerosols (Figure 6). In October, the difference in monthly mean temperature at these levels is greater than $0.5 \mathrm{~K}$ and only slightly smaller during November. Changes in temperature in September and December are smaller and less statistically significant. At the tropopause (118 hPa), strong cooling of $0.8 \mathrm{~K}$ is seen in October due to the presence of Indonesian aerosols along with a slight warming in the LS at $85 \mathrm{hPa}$. These effects will be discussed in more detail in section 4.6.

Figure 7 shows the horizontal distribution of temperature change associated with the Indonesian BB aerosols for SON. The largest increases in temperature occur in the Indonesian region, over Sumatra and the Karimata Strait, and in an area to the south over the Indian Ocean. A similar pattern of temperature increase is found at $200 \mathrm{and} 300 \mathrm{hPa}$. Though the largest impact on temperature is confined to Indonesia and the region directly 
to the south, warming averaging between 0.2 and $0.3 \mathrm{~K}$ is found over large areas of the Pacific Ocean.

\subsection{Circulation}

Heating caused by Indonesian aerosols also alters atmospheric circulation. Figure 8 shows profiles of the changes in grid-scale vertical mass flux, convective mass flux, and divergence in the Indonesian region. Diabatic heating by aerosols causes large increases in buoyancy with air rising throughout the troposphere. The impact is strongest in October with the largest increase in vertical mass flux at $400 \mathrm{hPa}$. Changes in convective mass flux are considerably smaller and demonstrate less statistical significance. The largest increases in convective mass flux occur between 600 and 700 $\mathrm{hPa}$. Small decreases in convective mass flux in October above $500 \mathrm{hPa}$ suggest that the increase in shallow convection may come at the expense of deeper convection capable of reaching the mid- to upper troposphere. Dickerson et al. [1997] noted that scattering aerosols tend to cool the boundary layer and stabilize the atmosphere with respect to convection. While absorbing aerosols in the boundary layer tend to destabilize the atmosphere, absorbing aerosols in the free troposphere increase stability (Dickerson et al., 1997). In the simulations presented here, convective available potential energy (CAPE) tends to decrease over Sumatra and Kalimantan when BB aerosols are simulated. Figure 6 shows that the greatest increases in temperature over Indonesia occur at $\sim 250 \mathrm{hPa}$ though the change in vertical mass flux is weaker at this level than at $400 \mathrm{hPa}$. This may be in part because warming of environmental air in the UT results in decreased buoyancy of air parcels lifted from below. 
Changes in grid-scale vertical motion are balanced by changes in the horizontal flow. In October, increased convergence occurs over Indonesia below $400 \mathrm{hPa}$. From 100 to $400 \mathrm{hPa}$, divergence increases with peak values found near $200 \mathrm{hPa}$. Increased divergence persists above the tropopause $(118 \mathrm{hPa})$ while at $85 \mathrm{hPa}$, a small increase in convergence occurs.

\subsection{Water Vapor}

The presence of Indonesian BB aerosols also alters the distribution of water vapor. Figure 9 shows the percentage change in specific humidity caused by changes in aerosol heating. Throughout the troposphere over Indonesia, aerosols increase the concentration of water vapor. Increases in buoyancy cause air to rise over Indonesia, bringing air with higher moisture content from lower altitudes. At low levels, this is balanced by increased convergence which replenishes the supply of moisture. In October, peak changes occur in the mid- to upper troposphere and can exceed $25 \%$ with a high degree of statistical significance. Specific humidity sharply decreases at the tropopause and in the layer above when Indonesian aerosol radiative effects are simulated. The evolution of these changes will be discussed in more detail in Section 4.6. Figure 10 shows the horizontal distribution of water vapor changes induced by aerosols at $250 \mathrm{hPa}$ for SON 2006. The largest impact is found over the Karimata Strait. Water vapor changes are more localized than temperature changes at this level and show little statistical significance outside of Indonesia.

\subsection{CO}

$\mathrm{CO}$, in addition to water vapor, is strongly affected by changes in vertical and horizontal advection associated with Indonesian fire aerosols. Figure 11 shows monthly 
profiles of CO for the AERO and NAERO ensembles as well as profiles of the change in CO mixing ratios over the Indonesian region. Large increases of $\mathrm{CO}$ occur in the mid- to upper troposphere with the largest increase of $80 \mathrm{ppbv}(\sim 50 \%)$ in October just below the tropopause. During October, decreases in CO are seen below $500 \mathrm{mb}$ which is in contrast to the specific humidity profiles (Figure 9) that showed an increase in moisture at low levels. When the radiative effects of Indonesian aerosols are simulated, upward transport of $\mathrm{CO}$ and water vapor increases, resulting in larger mixing ratios at upper levels. At low levels, increased horizontal convergence brings moist air into the Indonesian region. However, air parcels transported into the region horizontally have lower CO mixing ratios because they have not been exposed to strong $\mathrm{BB}$. As a result, $\mathrm{CO}$ mixing ratios in the lower troposphere decrease while water vapor increases. Water vapor profiles fail to show an upper tropospheric peak similar to those in $\mathrm{CO}$ profiles because the atmosphere in the UT is often near saturation, resulting in increases in upper tropospheric cloudiness as shown in Figure 5.

Figure 12 shows the horizontal distribution of the change in $\mathrm{CO}$ resulting from aerosol heating during SON 2006. Below the tropopause, at $150 \mathrm{hPa}$, peak changes in CO exceed $70 \mathrm{ppbv}$ over areas of Kalimantan and the Java Sea. Increases of up to 20 ppbv extend over the Pacific Ocean. At $100 \mathrm{hPa}$, just above the tropopause, peak CO changes are considerably smaller ( $20 \mathrm{ppbv})$ and occur over the Karimata Strait. Increases greater than $10 \mathrm{ppbv}$ extend over long distances in the Indian and Pacific Oceans. Changes in total CO mass in the TTL (region below the tropopause but above $150 \mathrm{mb}$ ), LS (region above the tropopause but below $60 \mathrm{hPa}$ ), and lowermost stratosphere (region above the tropopause but with potential temperature less than $380 \mathrm{~K}$ ) in the 
AERO simulations were calculated following Duncan et al. [2007a]. Mass perturbations include all latitudes and longitudes. It should be noted that the mass perturbations calculated here represent only the change resulting from simulating Indonesian aerosols and their radiative impacts; CO emissions are the same in both the AERO and NAERO ensembles and include $\mathrm{CO}$ produced by the Indonesian fires. Mass perturbations calculated by Duncan et al. [2007a] included emissions from the 1997 Indonesian fires but did not include the dynamic impacts of aerosols because they were computed in an offline CTM. Increased diabatic heating and lifting associated with Indonesian aerosols increases the mass of $\mathrm{CO}$ in the TTL by $7 \%$ in October and $9 \%$ in November (Figure 13). Changes in the stratosphere are smaller but persist longer with changes in the LS peaking at $5 \%$ in December, at the end of the 9-month simulations.

\subsection{Evolution of changes in UTLS dynamics}

Simulating the radiative affects of Indonesian BB aerosols leads to significant decreases in temperature and specific humidity at the tropopause. Figure 14 shows the daily evolution of changes in temperature, specific humidity, grid-scale vertical mass flux, horizontal divergence, cloud cover, and carbonaceous aerosol caused by the Indonesian fires. The largest increase in aerosols occurs during the period between September 20 and November 10 with a peak in aerosol mass in the UT on October 28. The maximum aerosol mass at $850 \mathrm{hPa}$ occurs in early October with a secondary maximum at the end of the month. Upward mass transport in the UT increases during this period with the largest increase occurring in early October. A small but statistically significant increase of upward mass flux also occurs at the tropopause (118 hPa). Though less statistically significant, increases in upward mass flux in the UT are 
accompanied by increased divergence. Daily increases in temperature in the UT are fairly constant throughout this period, ranging from 0-1 K per day at 300 and $200 \mathrm{hPa}$ and typically less than $0.5 \mathrm{~K}$ per day at $150 \mathrm{hPa}$. Large episodic increases in water vapor in the UT closely follow periods of increased upward motion.

Temperature changes at the tropopause and above show a higher degree of variability than those in the UT. Sharp decreases in temperature at the tropopause and increases at $85 \mathrm{hPa}$ occur from October 1 to October 15, the time period when the largest increase in upward motion occurs in the UT. During this period, convergence increases at $85 \mathrm{hPa}$ and is associated with a small degree of downward motion which brings warmer stratospheric air downward, increasing temperatures at this level. Temperature decreases at the tropopause are less intuitive. Changes in the radiative heating rates (Figure 5a) indicate a small amount of net heating in the vicinity of the tropopause. An analysis of model tendency terms due to moist processes indicates that these processes have a relatively small impact on temperature in the vicinity of the tropopause meaning that the cause of these temperature decreases is likely dynamical in nature. Upward motion caused by increased buoyancy affects temperature in two ways; in the troposphere, warmer air is lofted from below which tends to increase air temperature at upper levels. At the same time, as air parcels are lifted to lower pressures, they experience adiabatic cooling. Vertical temperature advection and adiabatic cooling largely offset throughout the troposphere with the net effect on temperature governed by the difference between the environmental and dry adiabatic lapse rates. The environmental lapse rate is typically less than the dry adiabatic rate which implies net cooling in rising air parcels when diabatic changes are not considered. Throughout the 
troposphere, diabatic changes such as increases in short wave heating due to aerosols dominate. At the tropopause, in the absence of strong diabatic heating changes caused by Indonesian aerosols, dynamical changes induced by the aerosols exert a stronger influence. As air is lifted near the tropopause, the environmental lapse rate becomes considerably smaller than the dry adiabatic lapse rate. In this region, rising air causes strong cooling as adiabatic cooling dominates vertical temperature advection.

Decreases in water vapor occur at the tropopause in October in the same areas associated with rising air and temperature decreases. Because temperature decreases lower the saturation vapor pressure, relative humidity actually increases though the total amount of water vapor is less. This level is also where the greatest increase in cloudiness is found. The decrease in water vapor at the tropopause is approximately equal to the increase in cloud ice mass indicating that the decrease in water vapor is associated with decreases in temperature and increases in cloudiness.

\section{Summary and conclusions}

Duncan et al. [2007a] previously demonstrated that Indonesian fires in 1997 could alter the chemistry and composition of the TTL and LS using an offline CTM. Here, we present results examining the influence of aerosols produced by 2006 fires on atmospheric dynamics using ensemble simulations of the GEOS-5 AGCM which include aerosol direct and semi-direct effects. Clear-sky TOA radiative forcings were as large as $-30 \mathrm{~W} \mathrm{~m}^{-2}$ over Indonesia in October, though increases in cloud radiative forcings associated with the aerosols tend to be of opposite sign. Stronger impacts were found at the surface where clear-sky radiative forcings as low as $-220 \mathrm{~W} \mathrm{~m}^{-2}$ were found over Indonesia. 
Duncan et al. [2003] estimated clear-sky aerosol radiative forcings at the surface as low as $-178 \mathrm{~W} \mathrm{~m}^{-2}$ during October 1997 over Indonesia. In the Duncan et al. [2003] simulations of the 1997 event, the aerosol plume affected large areas of the Indian and Pacific Oceans with radiative forcing less than $-5 \mathrm{~W} \mathrm{~m}^{-2}$ found as far away as Africa. In our simulations, negative peaks in radiative forcing are stronger over the burning region but the horizontal extent of the aerosol plume is considerably smaller than in the Duncan et al. [2003] simulations of the 1997 event. This pattern is consistent with the GFEDv2 emissions of BC and OC. Emissions of carbonaceous aerosols from all Indonesian land regions were higher by a factor of 1.9 (4.4) in August (September) of 1997 compared to the same months in 2006. In contrast, during October, emissions were only $26 \%$ greater in 1997 than in 2006. Aerosol emissions from Kalimantan were 3.5 times greater in September 1997 than in September 2006, but during October, emissions were nearly equal in both years. Over the southwest portion of Kalimantan (south of the equator and west of 115E) where the peak in direct aerosol radiative forcing is found in our simulations, aerosol emissions from the GFEDv2 inventory were $8 \%$ greater during October 2006 than October 1997. Though the 1997 Indonesian fires were stronger than the 2006 fires and produced more total aerosol mass, the slightly elevated emissions over southwest Kalimantan during October 2006 produce a peak radiative forcing that is comparable to the peak forcings calculated by Duncan et al. [2003] for the 1997 event. Because burning was significantly weaker during August and September of 2006, the area influenced by Indonesian BB aerosols during October of that year is considerably smaller than the area influenced by the 1997 event. 
Temperatures over Indonesia were strongly modified by increased diabatic heating during the period of burning. The largest increases were found in October and November between 150 and $400 \mathrm{hPa}$. In some regions, increases exceeded $0.7 \mathrm{~K}$ during SON. In addition to significant warming in the UT, aerosol heating caused strong cooling at the tropopause in October as air parcels rising in the vicinity of the tropopause experienced strong adiabatic cooling.

Diabatic heating from Indonesian fire aerosols increased temperature and buoyancy throughout the troposphere in October resulting in large increases in upward motion over the region. Increases in vertical motion were accompanied by changes in the horizontal flow. Below $400 \mathrm{hPa}$, increasing convergence occurred over Indonesia while increases in divergence were found between 100 and $400 \mathrm{hPa}$. Water vapor mixing ratios increased throughout the troposphere with the largest increases in terms of percentage occurring in October at $400 \mathrm{hPa}$ as stronger updrafts carried air with larger moisture contents to higher levels. In the UT, increases in water vapor are smaller than below because more water vapor is converted to cloud ice as cloud cover increases. At the tropopause and in the layer above, temperatures lowered by adiabatic cooling contribute to decreased water vapor and increased cloud formation in October.

Increases in upward motion also affect the transport of BB pollution to the UTLS. CO mixing ratios are increased by over $80 \mathrm{ppbv}(\sim 50 \%)$ in October just below the tropopause. An analysis of $\mathrm{CO}$ mass indicated that aerosol heating increased the mass of CO in the TTL by $9 \%$ in November. Changes in the LS were smaller and lagged those in the TTL but in December were as large as $5 \%$. 
Duncan et al. [2007] used an offline CTM to examine the impact of the 1997 Indonesian fires on cross-tropopause transport. Their results indicated that increased CO mixing ratios could reduce $\mathrm{OH}$ mixing ratios, increasing atmospheric lifetimes and troposphere-to-stratosphere transport of a number of trace gases. While the present study does not consider chemical effects, our results demonstrate that diabatic heating from Indonesian fire aerosols can strongly influence circulation and composition in the UTLS and may also play a significant role in troposphere-to-stratosphere transport. Though we have only simulated the transport of $\mathrm{CO}$, it is likely that aerosol heating also influences the transport of other species produced by fire events such as $\mathrm{CO}_{2}, \mathrm{NO}_{\mathrm{x}}$, methane and non-methane hydrocarbons to the UTLS. It is necessary for GCMs to include realistic representations of aerosols which fully represent the interannual variability of BB emissions in order to capture these effects.

Climate models which include both chemistry and dynamics are needed to fully understand the complex effects of aerosols on atmospheric transport. It should be noted that the study presented here has several limitations. The aerosol indirect affect was not included in these simulations. Langmann [2007] studied the impact of aerosols from the 1997 Indonesian fires on cloud and precipitation formation (second indirect effect) using a regional climate model. Their results indicated that smoke aerosols often suppressed precipitation, resulting in increased cloud top heights for shallow clouds and decreased cloud top heights for deep convective clouds; in some cases, the presence of smoke aerosols increased precipitation and resulted in shallower low clouds and deeper convective clouds (Langmann, 2007). Our results indicate that aerosol direct and semidirect effects increased cloudiness over Indonesia in 2006 with the greatest impact found 
in the UTLS. Further studies are needed to examine the collective impacts of direct, indirect, and semi-direct effects on cloud and precipitation processes though much uncertainty remains regarding the role of aerosol indirect effects (i.e. IPCC, 2007).

These simulations did not consider the influence of aerosols on SSTs. Rajeev et al. [2008] found that the 1997 Indonesian fires reduced SSTs by 1 to $2{ }^{\circ} \mathrm{C}$ in the eastern equatorial Indian Ocean and suggested that the impact could potentially strengthen the Indian Ocean Dipole. The increases in cloudiness found in our ensemble simulations could also influence SSTs but studies with coupled atmosphere-ocean GCMs are needed to fully understand how aerosol-induced changes in SST drive atmospheric circulation. For simplicity, the ensemble simulations presented here used aerosol forcing fields calculated offline. Future studies will focus on understanding how changes in dynamics alter aerosol distributions through changes in horizontal and vertical advection and wet removal.

This work also demonstrates the importance of ensemble simulations in understanding the role of aerosol forcing in the climate system. Ten-member ensembles were sufficient for examining changes in dynamics in the Indonesian region as indicated by statistical analysis using the Student's t-test, but larger ensembles are necessary to identify potential climate teleconnections and impacts outside of the immediate source region. As computer models increase in complexity, internal model variability is likely to increase, requiring even larger ensembles to discern statistically significant changes.

\section{References}

Arakawa, A., and W. H. Schubert (1974), Interaction of a Cumulus Cloud Ensemble with the Large-Scale Environment, Part I, J. Atmos. Sci., 31, 674-701. 
Bian, H., M. Chin, S. R. Kawa, B. Duncan, A. Arellano, and P. Kasibhatla (2007), Sensitivity of global CO simulations to uncertainties in biomass burning sources, J. Geophys. Res., 112, D23308, doi:10.1029/2006JD008376.

Chandra, S., J. R. Ziemke, B. N. Duncan, T. L. Diehl, N. J. Livesey, and L. Froidevaux (2009), Effects of the $2006 \mathrm{El}$ Niño on tropospheric ozone and carbon monoxide: implications for dynamics and biomass burning, Atmos. Chem. Phys., 9, 4239-4249.

Chin, M., P. Ginoux, S. Kinne, B. N. Holben, B. N. Duncan, R. V. Martin, J. A. Logan, A. Higurashi, and T. Nakajima (2002), Tropospheric aerosol optical thickness from the GOCART model and comparisons with satellite and sunphotometer measurements, $J$. Atmos. Sci. 59, 461-483.

Chou, M.-D., and M. J. Suarez (1994), An efficient thermal infrared radiation parameterization for use in general circulation models, NASA Tech. Memo 104606, 3, 85 pp.

Chou, M.-D., and M. J. Suarez (2002), A solar radiation parameterization for atmospheric studies, NASA Tech. Memo 104606, 15, 40 pp.

Chou, M.-D., M. J. Suarez, X.-A. Liang, and M. M.-H. Yan (2003), A thermal infrared radiation parameterization for atmospheric studies, NASA Tech. Memo 104606, 19, 85 pp.

Chung, C. E., and V. Ramanathan, (2006). Weakening of North Indian SST Gradients and the Monsoon Rainfall in India and the Sahel, J. Climate, 19, 2036-2045.

Dickerson, R. R., S. Kondragunta, G. Stenchikov, K. L. Civerolo, B. G. Doddridge, and B. Holben (1997), The Impact of Aerosols on Solar UV Radiation and Photochemical Smog, Science, 278(5339), 827-830.

Duncan, B. N., R. V. Martin, A. C. Staudt, R. Yevich, and J. A. Logan (2003), Interannual and seasonal variability of biomass burning emissions constrained by satellite observations, J. Geophys. Res., 108(D2), 4100, doi:10.1029/2002JD002378.

Duncan, B. N., S. E. Strahan, Y. Yoshida, S. D. Steenrod, and N. Livesey (2007a), Model study of the cross-tropopause transport of biomass burning pollution, Atmos. Chem. Phys., 7, 3713-3736.

Duncan, B. N., J. A. Logan, I. Bey, I. A. Megretskaia, R. M. Yantosca, P. C. Novelli, N. B. Jones, and C. P. Rinsland (2007b), The global budget of CO, 1988-1997: source estimates and validation with a global model, J. Geophys. Res., 112, D22301, doi: 10.1029/2007JD008459. 
Duncan, B. N., and J. A. Logan (2008), Model analysis of the factors regulating the trends and variability of carbon monoxide between 1988 and 1997, Atmos. Chem. Phys., 8, 7389-7403.

Field, R. D., G. R. van der Werf, and S. S. P. Shen (2009), Human amplification of drought-induced biomass burning in Indonesia since 1960, Nature Geoscience, 2, doi: 10.1038/ngeo443.

Filipiak, M., R. Harwood, J. Jiang, et al. (2005) Carbon monoxide measured by the EOS Microwave Limb Sounder on Aura: First results, Geophys. Res. Lett., 32, L14825, doi:10.1029/2005GL022765.

Guenther, A., C. N. Hewitt, D. Erickson, et al. (1995), A global model of natural volatile organic compound emissions, J. Geophys. Res., 100, 8873-8892.

Hargreaves, J. C., A. Abe-Ouchi, and J. D. Annan (2007), Linking glacial and future climates through an ensemble of GCM simulations, Clim. Past, 3, 77-87.

Huebener, H., U. Cubasch, U. Langematz, T. Spangehl, F. Niehörster, I. Fast, and M. Kunze (2007), Ensemble climate simulations using a fully coupled ocean-tropospherestratosphere general circulation model, Phil. Trans. R. Soc. A, 15, 365, doi: 10.1098/rsta. 2007.2078.

IPCC (2007), Climate Change 2007: Synthesis Report. Contribution of Working Group I to the Fourth Assessment Report of the Intergovernmental Panel on Climate Change S. Solomon et al. (eds.) Cambridge University Press, 996 pp.

Jaenicke, J. et al. (2008), Determination of the amount of carbon stored in Indonesian peatlands, Geoderma, 147, 151-158.

Koster, R. D., M. J. Suarez, A. Ducharne, M. Stieglitz, and P. Kumar, (2000), A catchment-based approach to modeling land surface processes in a GCM, Part 1, Model Structure, J. Geophys. Res., 105, 24809-24822.

Langmann, B. (2007), A model study of smoke-haze influence on clouds and warm precipitation formation in Indonesia 1997/1998, Atmos. Env., 41, doi:10.1016/j.atmosenv. 2007.04.050.

Lau, K. M., M. K. Kim, and K. M. Kim (2006), Asian monsoon anomalies induced by aerosol direct effects, Clim. Dyn., 26, 855-864, doi:10.1007/s00382-006-0114-z.

Lau, K.-M., and K.-M. Kim (2006), Observational relationships between aerosol and Asian monsoon rainfall, and circulation, Geophys. Res. Lett., 33, L21810, doi: 10.1029/2006GL027546. 
Li, Z. X. (1999), Ensemble Atmospheric GCM Simulation of Climate Interannual Variability from 1979 to 1994, J. Climate, 12, 986-1001.

Lin, S.-J. (2004), A "vertically Lagrangian" finite-volume dynamical core for global models, Mon. Wea. Rev., 132(10):2293-2307.

Livesey, N. J., et al. (2008), Validation of Aura Microwave Limb Sounder O3 and CO observations in the upper troposphere and lower stratosphere, J. Geophys. Res., 113, D15S02, doi:10.1029/2007JD008805.

Lock, A. P., A. R. Brown, M. R. Bush, G. M. Martin, and R. N. B. Smith (2000), A New Boundary Layer Mixing Scheme. Part I: Scheme Description and Single-Column Model Tests, Mon. Wea. Rev., 128, 3187-3199.

Logan, J. A., I. Megretskaia, R. Nassar, L. T. Murray, L. Zhang, K. W. Bowman, H. M. Worden, and M. Luo (2008), Effects of the 2006 El Niño on tropospheric composition as revealed by data from the Tropospheric Emission Spectrometer (TES), Geophys. Res. Lett., 35, L03816, doi:10.1029/2007GL031698.

Menon, S., J. E. Hansen, L. Nazarenko, and Y. Luo (2002), Climate effects of black carbon aerosols in China and India, Science, 297, 2250-2253, doi:10.1126/science. 1075159.

Ming, Y., and V. Ramaswamy (2009), Nonlinear Climate and Hydrological Responses to Aerosol Effects, J. Climate, 22, 1329-1339.

Moorthi S., and M. J. Suarez (1992), Relaxed Arakawa-Schubert: A parameterization of moist convection for general circulation models, Mon. Wea. Rev., 120, 978-1002.

Ott, L. E., S. Pawson, and J. Bacmeister (2009), An analysis of the impact of convective parameter sensitivity on simulated global atmospheric CO distributions, in preparation for Atmospheric Chemistry and Physics.

Page, S. E., F. Siegert, J. O. Rieley, H.-D. V. Boehm, A. Jaya, and S. Limin (2002), The amount of carbon released from peat and forest fires in Indonesia during 1997, Nature, 420, doi:10.1038/nature01131.

Podgorny, I. A., F. Li, and V. Ramanathan (2003), Large Aerosol Radiative Forcing due to the 1997 Indonesian Forest Fire, Geophys. Res. Lett., 30(1), 1028, doi: 10.1029/2002GL015979.

Rajeev, K., K. Parameswaran, S. K. Nair, and S. Meenu (2008), Observational evidence for the radiative impact of Indonesian smoke in modulating the sea surface temperature of the equatorial Indian Ocean, J. Geophys. Res., 113, D17201, doi: 10.1029/2007JD009611. 
Ramanathan, V. and P. J. Crutzen 2003, New Directions: Atmospheric Brown "Clouds", Atmos. Env., 37(28), 4033-4035.

Ramaswamy, V., et al., Radiative forcing of climate change, in Climate Change 2001, edited by J. T. Houghton et al., Pp. 239-287, Cambridge Univ. Press, New York, 2001.

Randles, C. A., and V. Ramaswamy (2008), Absorbing aerosols over Asia: A Geophysical Fluid Dynamics Laboratory general circulation model sensitivity study of model response to aerosol optical depth and aerosol absorption, J. Geophys. Res., 113, D21203, doi:10.1029/2008JD010140.

Reinecker, M. M., Suarez, M. J., Todling, R., et al. (2008), The GEOS-5 Data Assimilation System-Documentation of Versions 5.0.1, 5.1.0, and 5.2.0, Tech. Rep. 104606 V27, NASA.

Reynolds, R. W., T. M. Smith, C. Liu, D. B. Chelton, K. S. Casey, and M. G. Schlax, 2007: Daily high-resolution blended analyses for sea surface temperature. J. Climate, 20, 5473-5496.

Rudich, Y., A. Sagi and D. Rosenfeld (2003), The influence of the Kuwait oil fires plume (1991) on the microphysical development of clouds, J. of Geophys. Res., 108 (D15), 4478 doi:10.1029/2003JD003472.

Taschetto, A. S., and M. H. England (2008), Estimating ensemble size requirements of AGCM simulations, Met. and Atmos. Phys., 100, 23-36.

Thampi, B. V., K. Rajeev, K. Parameswaran, and M. K. Mishra (2009), Spatial distribution of the Southeast Asian smoke plume over the Indian Ocean and its radiative heating in the atmosphere during the major fire event of 2006, Geophys. Res. Lett., 36, L16808, doi:10.1029/2009GL039316.

van der Werf, G. R., J. T. Randerson, G. J. Collatz, and L. Giglio (2003), Carbon emissions from fires in tropical and subtropical ecosystems, Global Change Biology, 9 (4): 547-562.

van der Werf, G. R., J. T. Randerson, L. Giglio, G. J. Collatz, P. S. Kasibhatla, and A. F. Arellano Jr. (2006), Interannual variability in global biomass burning emissions from 1997 to 2004, Atmos. Chem. Phys., 6, 3423-3441.

Vitart, F., J. L. Anderson, and W.F. Stern (1997), Simulation of Interannual Variability of Tropical Storm Frequency in an Ensemble of GCM Integrations, J. Climate, 10, 745-760.

Wang, Y., R. D. Field, and O. Roswintiarti (2004), Trends in atmospheric haze induced by peat fires in Sumatra Island, Indonesia and El Niño phenomenon from 1973 to 2003, Geophys. Res. Lett., 31, L04103, doi:10.1029/2003GL018853. 
Wehner, M. F. (2000), A method to aid in the determination of the sampling of AGCM ensemble simulations, Clim. Dyn., 16, 321-31

Yevich, R., and J. A. Logan (2003), An assessment of biofuel use and burning of agricultural waste in the developing world, Global Biogeochem. Cycles, 17(4), 1095, doi: 10.1029/2002GB001952.

Yu, H., M. Chin, D. M. Winker, A. H. Omar, Z. Liu, C. Kittaka, and T. Diehl (2009), Global view of aerosol vertical distributions from CALIPSO lidar measurements and GOCART simulations: Regional and seasonal variations, submitted to J. Geophys. Res.

Ziemke, J.R., S. Chandra, B. N. Duncan, M. R. Schoeberl, O. Torres, M. R. Damon, and P.K. Bhartia (2009), Recent biomass burning in the tropics and related changes in tropospheric ozone, Geophys. Res. Lett., doi:10.1029/2009GL039303, in press.

Zhu, Y. and R. Gelaro (2008), Observation Sensitivity Calculations Using the Adjoint of the Gridpoint Statistical Interpolation (GSI) Analysis System, Mon. Wea. Rev., 136, 335-351. 


\section{Figures}

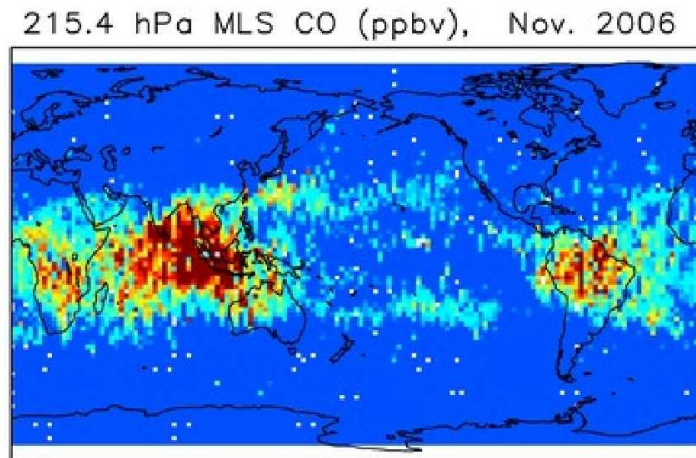

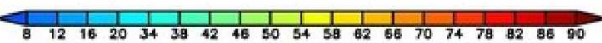

$215.4 \mathrm{hPa}$ GEOS-5 CO (ppbw), Nov. 2006
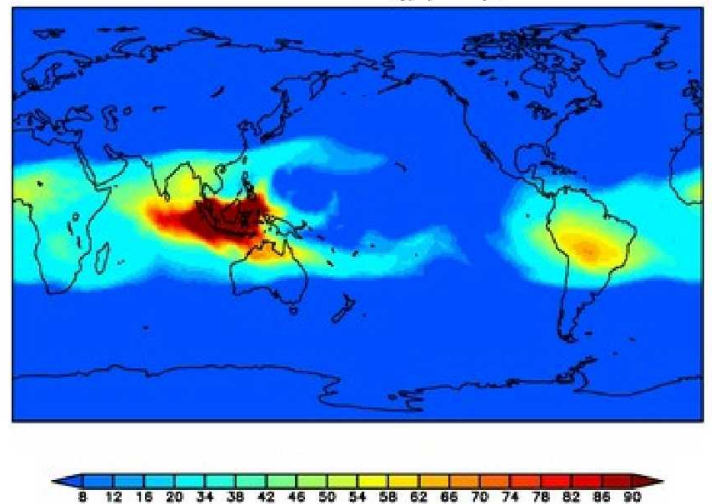

Figure 1. November 2006 MLS CO perturbation mixing ratios at $215.4 \mathrm{hPa}$ (left) and GEOS-5 simulated CO mixing ratios (right) in ppbv (calculated by subtracting the MLS global mean from observed MLS CO mixing ratios and subtracting the GEOS-5 global mean from simulated GEOS-5 CO mixing ratios). GEOS-5 CO at $215.4 \mathrm{hPa}$ is calculated by averaging $\mathrm{CO}$ over 5 model layers $(\sim 4 \mathrm{~km})$ in order to approximate the vertical resolution of MLS. 


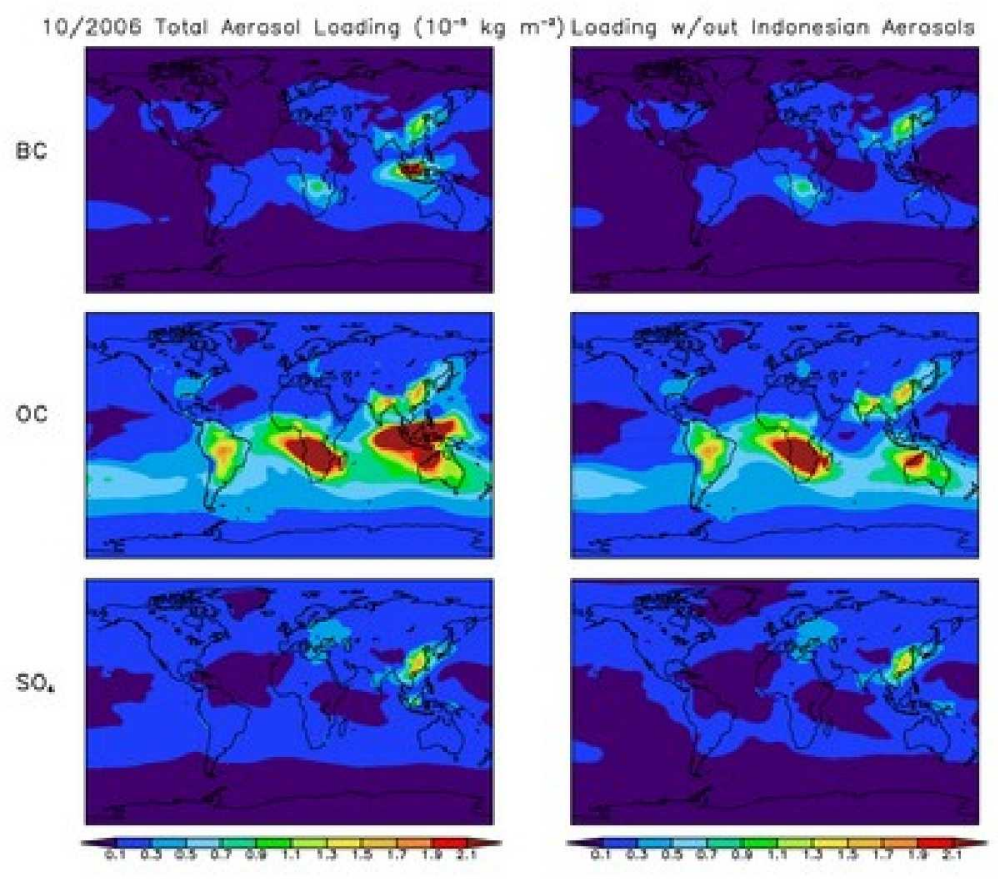

Figure 2. Column loading $\left(10^{-5} \mathrm{~kg} \mathrm{~m}^{-2}\right)$ of black carbon (BC: top), organic carbon (OC: middle), and sulfate (bottom) aerosol produced by GOCART CTM simulations and used to force the AERO (left) and NAERO (right) GEOS-5 ensembles. The fields shown are for October 2006. 

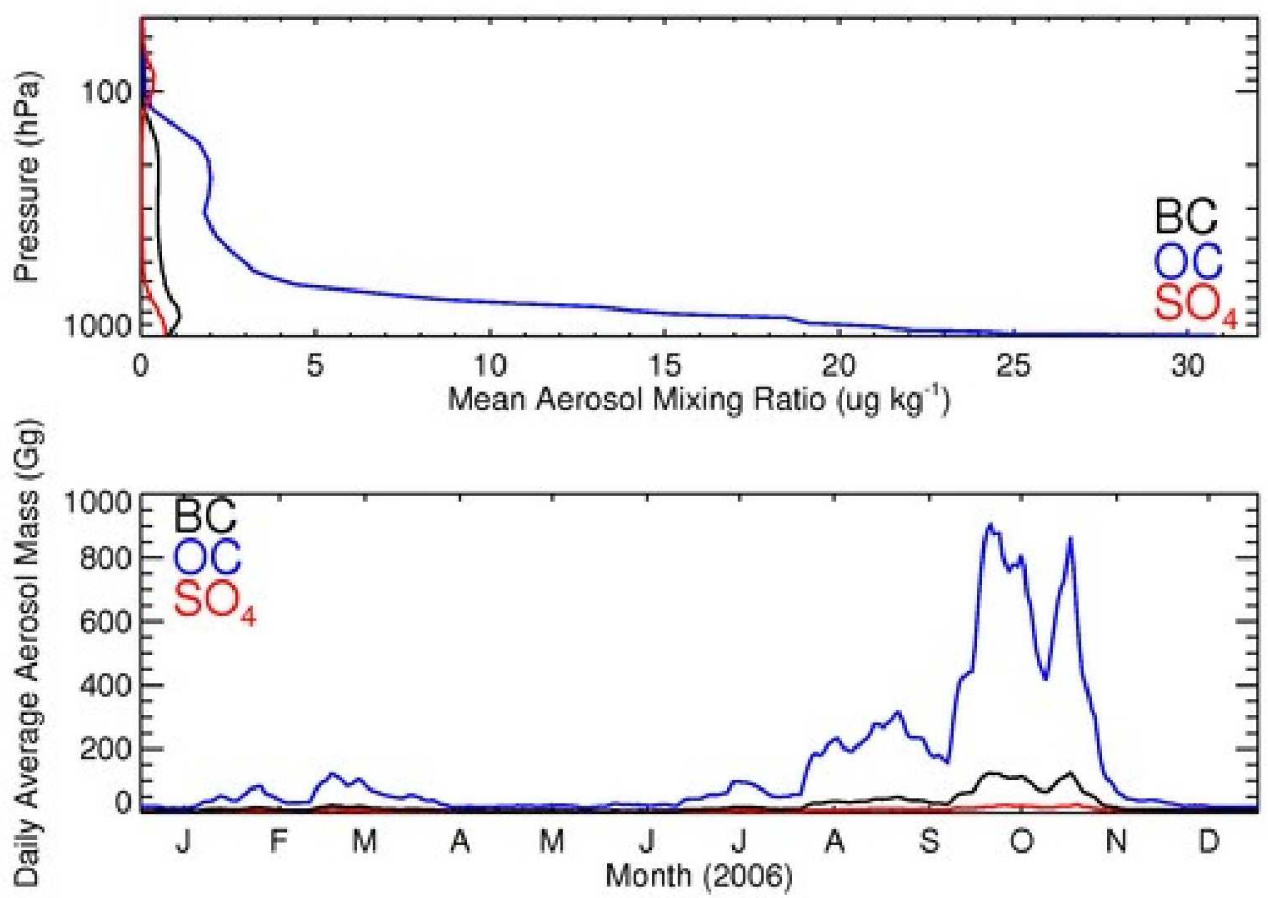

Figure 3. Aerosol distributions over Indonesia used in the AERO simulations. The top panel shows the vertical distributions of BC (black), OC (blue), and sulfate (red) aerosol mass mixing ratios calculated during SON 2006 over the Indonesian region $\left(100^{\circ}\right.$ to $120^{\circ} \mathrm{E}$ and $10^{\circ} \mathrm{S}$ to $10^{\circ} \mathrm{N}$ ). The bottom panel shows the annual cycle of total aerosol mass for each of the three aerosol types over the Indonesian region. 

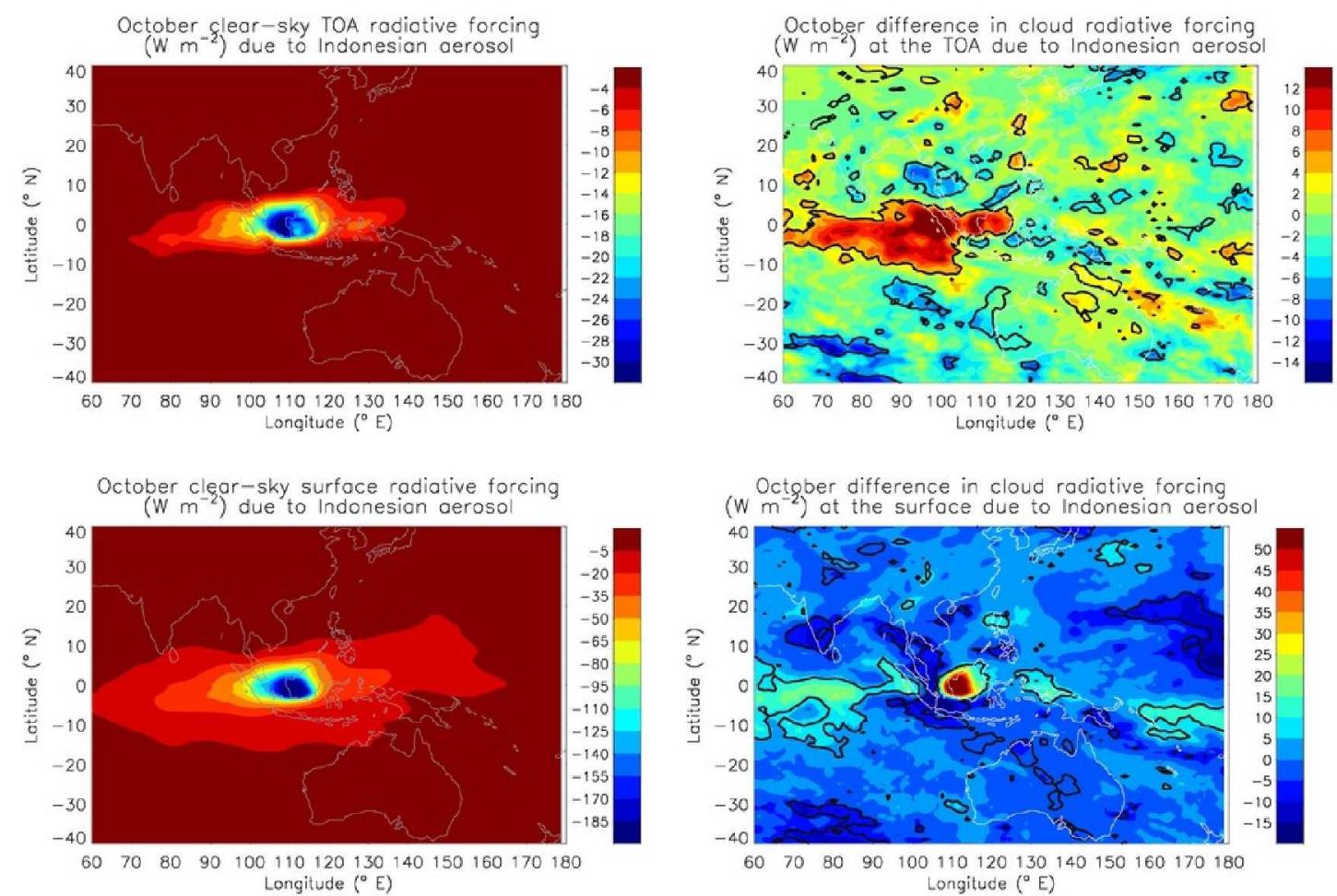

Figure 4. Clear-sky radiative forcing at the TOA (top left) and surface (bottom left) resulting from Indonesian aerosols calculated using GOCART AERO and NAERO aerosol distributions. Radiative forcing due to changes in cloudiness associated with Indonesian aerosols at the TOA (top right) and surface (bottom right) calculated by subtracting the NAERO ensemble mean from the AERO ensemble mean. Black contours indicate regions where the Student's t-test indicates differences between ensembles are statistically significant at the $95 \%$ confidence level. 
(a)

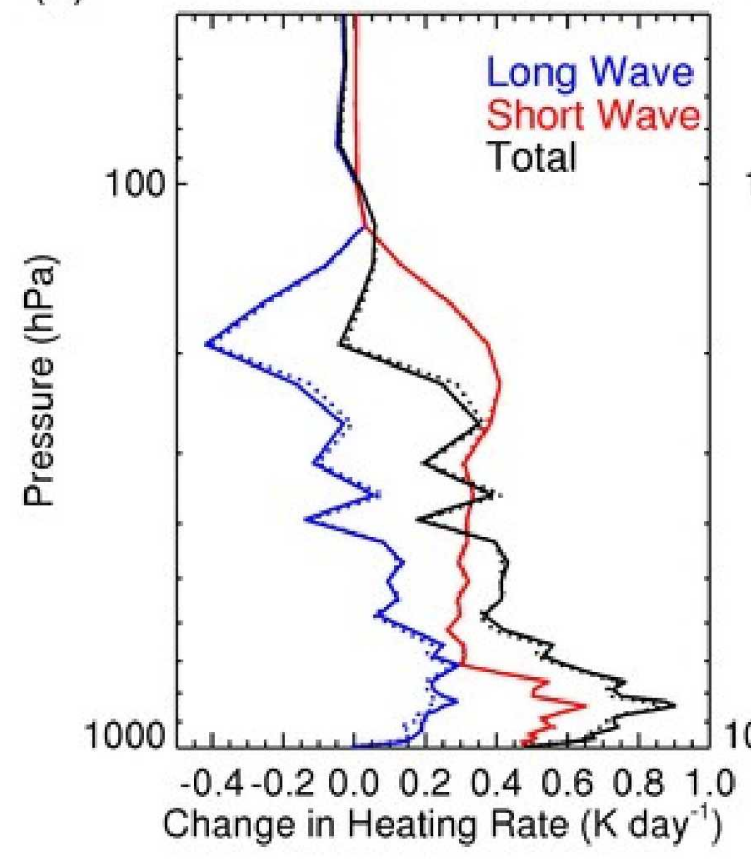

(b)

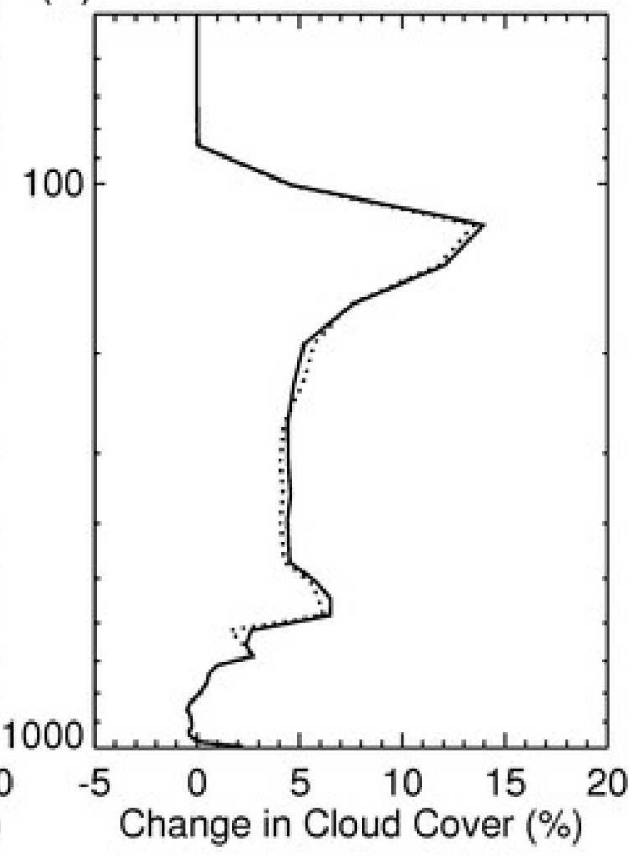

Figure 5. (a) Changes in long wave (blue), short wave (red), and total (black) radiative heating rate and (b) changes in percentage cloud cover during October, 2006 due to Indonesian aerosols (AERO ensemble mean minus NAERO ensemble mean). Solid lines indicate profiles calculated over all grid cells between $100^{\circ}$ to $120^{\circ} \mathrm{E}$ and $10^{\circ} \mathrm{S}$ to $10^{\circ} \mathrm{N}$ while dotted lines indicate profiles including only grid cells in which the Student's t-test indicated statistically significant differences. 


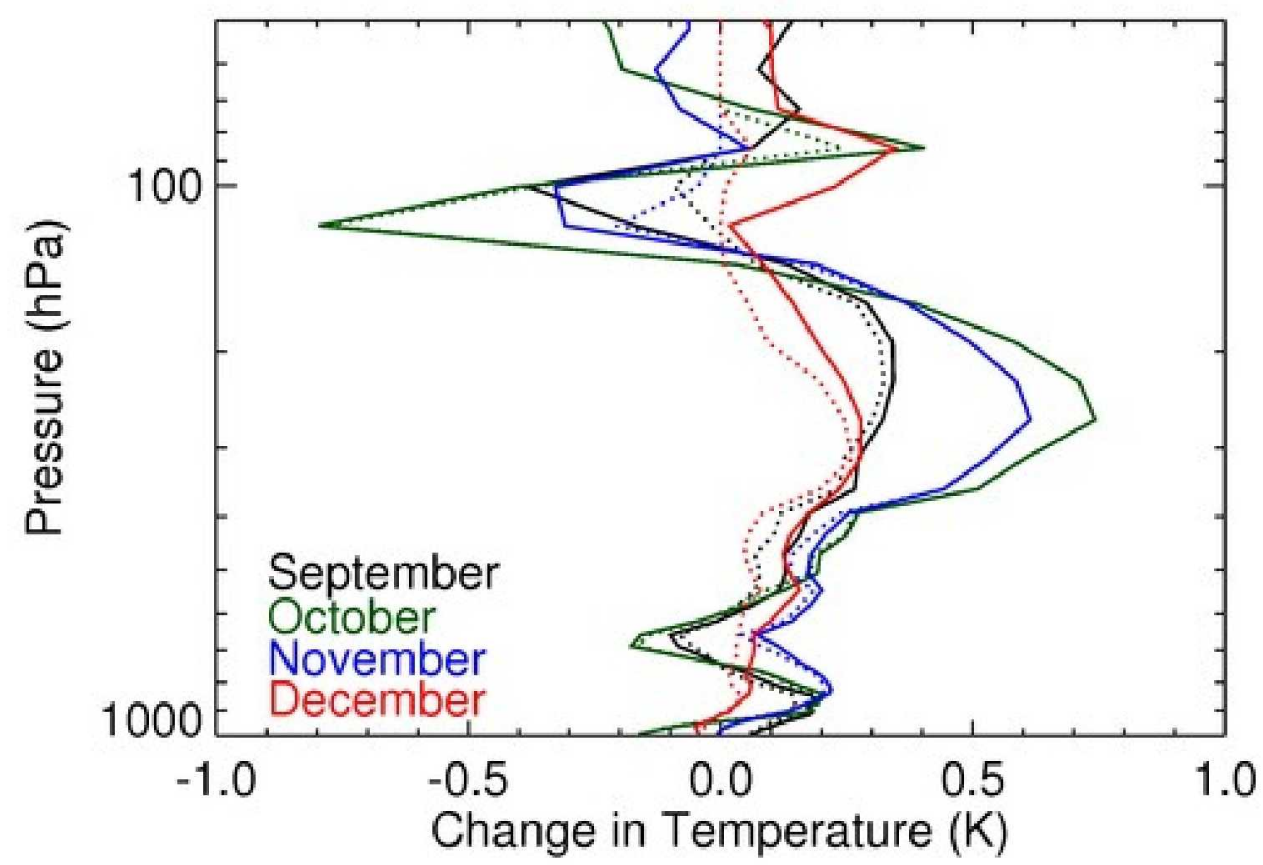

Figure 6. Changes in temperature due to Indonesian aerosols (AERO ensemble mean minus NAERO ensemble mean) during September (black), October (green), November (blue), and December (Red). Solid lines indicate profiles calculated over all grid cells between $100^{\circ}$ to $120^{\circ} \mathrm{E}$ and $10^{\circ} \mathrm{S}$ to $10^{\circ} \mathrm{N}$ while dotted lines indicate profiles including only grid cells in which the Student's t-test indicated statistically significant differences. 


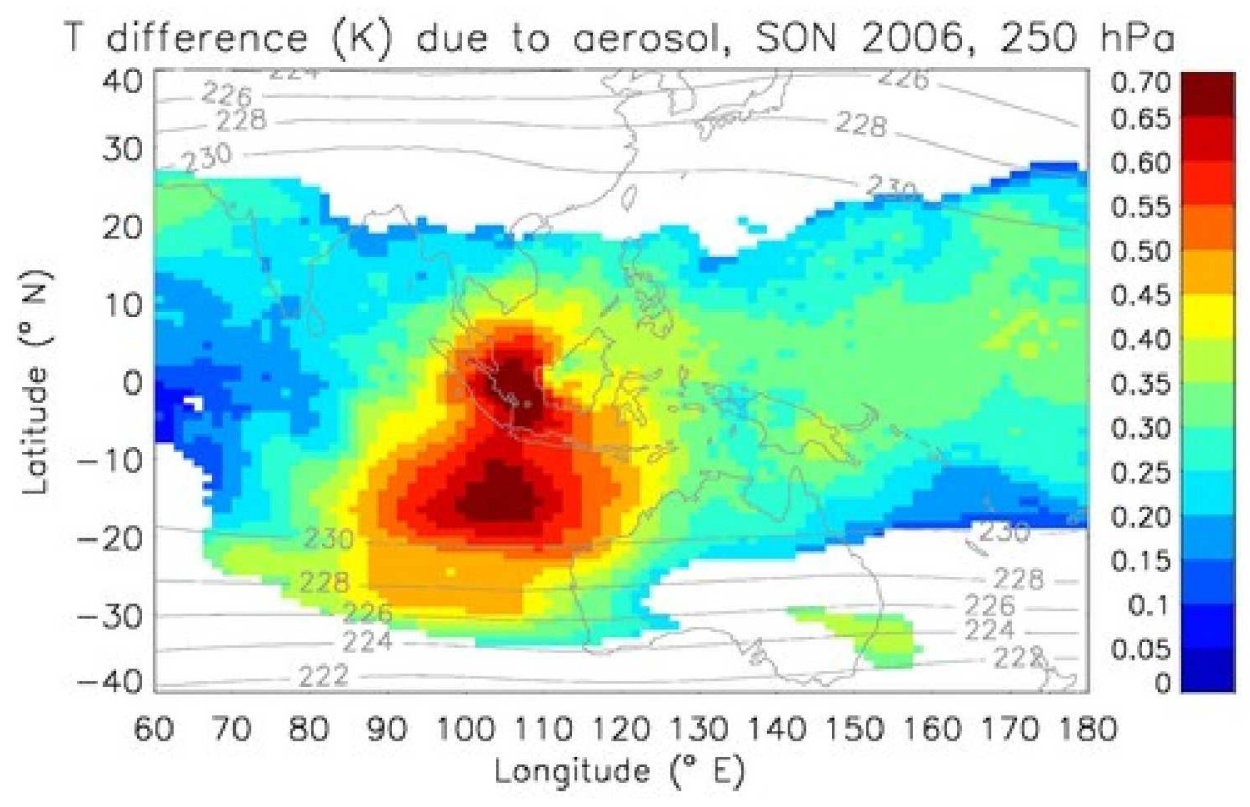

Figure 7. Average temperature difference during SON 2006 at $250 \mathrm{hPa}$ resulting from simulating the effects of Indonesian BB aerosols (AERO ensemble mean minus NAERO ensemble mean). Only statistically significant (as indicated by the Student's t-test) grid column differences are shown. Grey contours show AERO ensemble-mean temperatures. 
(a)

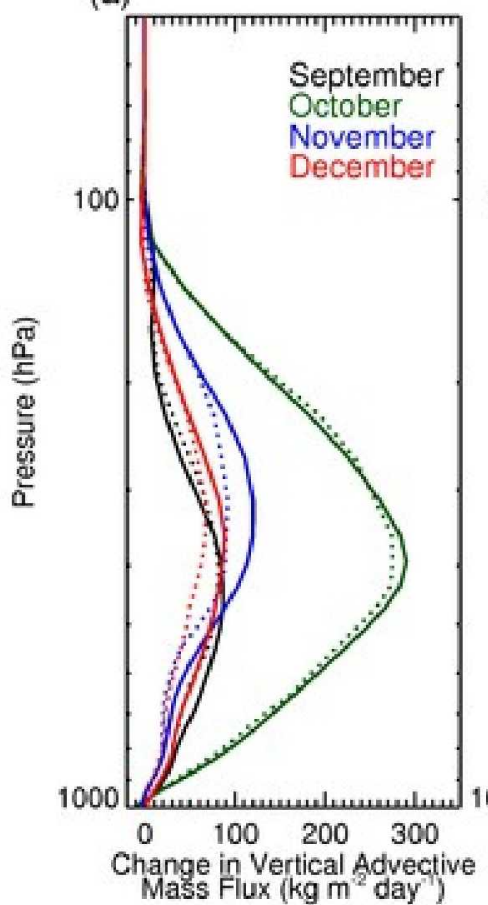

(b)

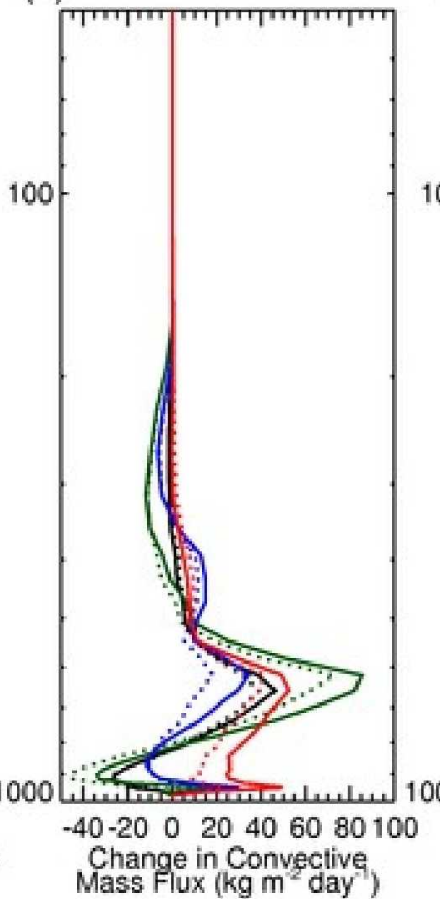

(c)

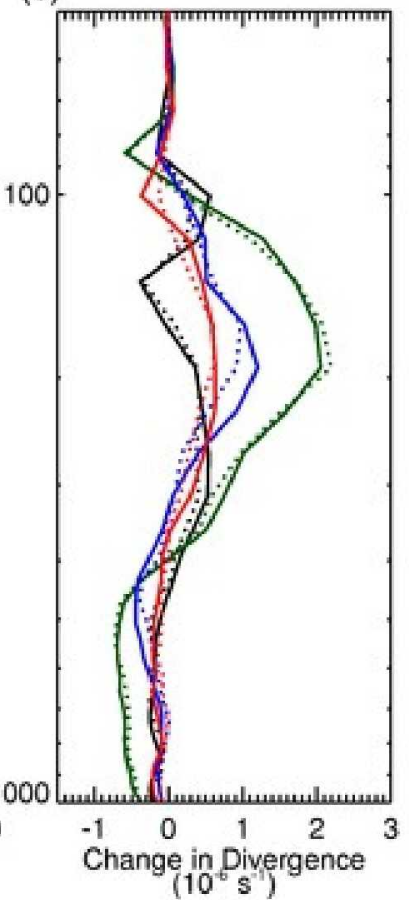

Figure 8. Changes in vertical grid-scale mass flux (a), convective mass flux (b), and horizontal divergence (c) due to Indonesian aerosols (AERO ensemble mean minus NAERO ensemble mean) in September (black), October (green), November (blue), and December (Red). Solid lines indicate profiles calculated over all grid cells between $100^{\circ}$ to $120^{\circ} \mathrm{E}$ and $10^{\circ} \mathrm{S}$ to $10^{\circ} \mathrm{N}$ while dotted lines indicate profiles including only grid cells in which the Student's t-test indicated statistically significant differences. 


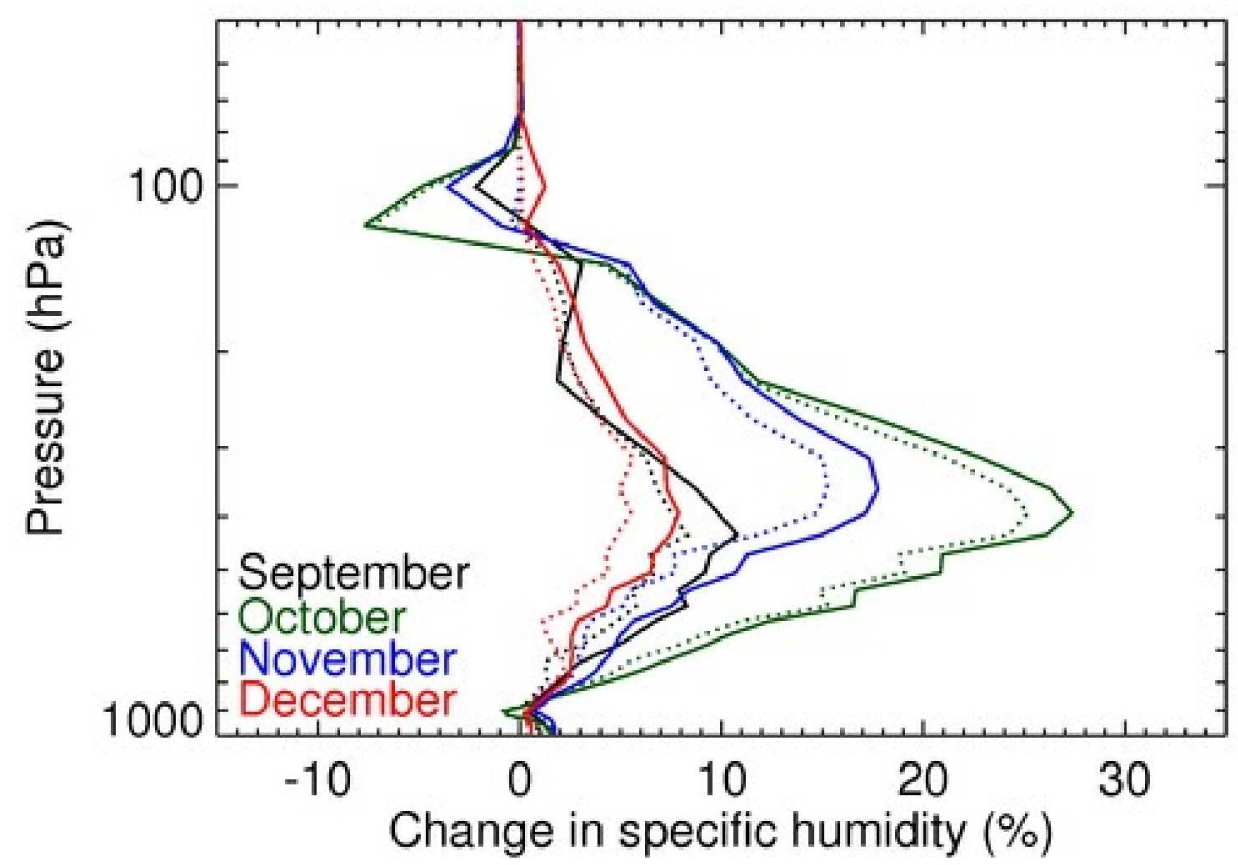

Figure 9. Changes in specific humidity due to Indonesian aerosols (AERO ensemble mean minus NAERO ensemble mean) during September (black), October (green), November (blue), and December (Red). Solid lines indicate profiles calculated over all grid cells between $100^{\circ}$ to $120^{\circ} \mathrm{E}$ and $10^{\circ} \mathrm{S}$ to $10^{\circ} \mathrm{N}$ while dotted lines indicate profiles including only grid cells in which the Student's t-test indicated statistically significant differences. 


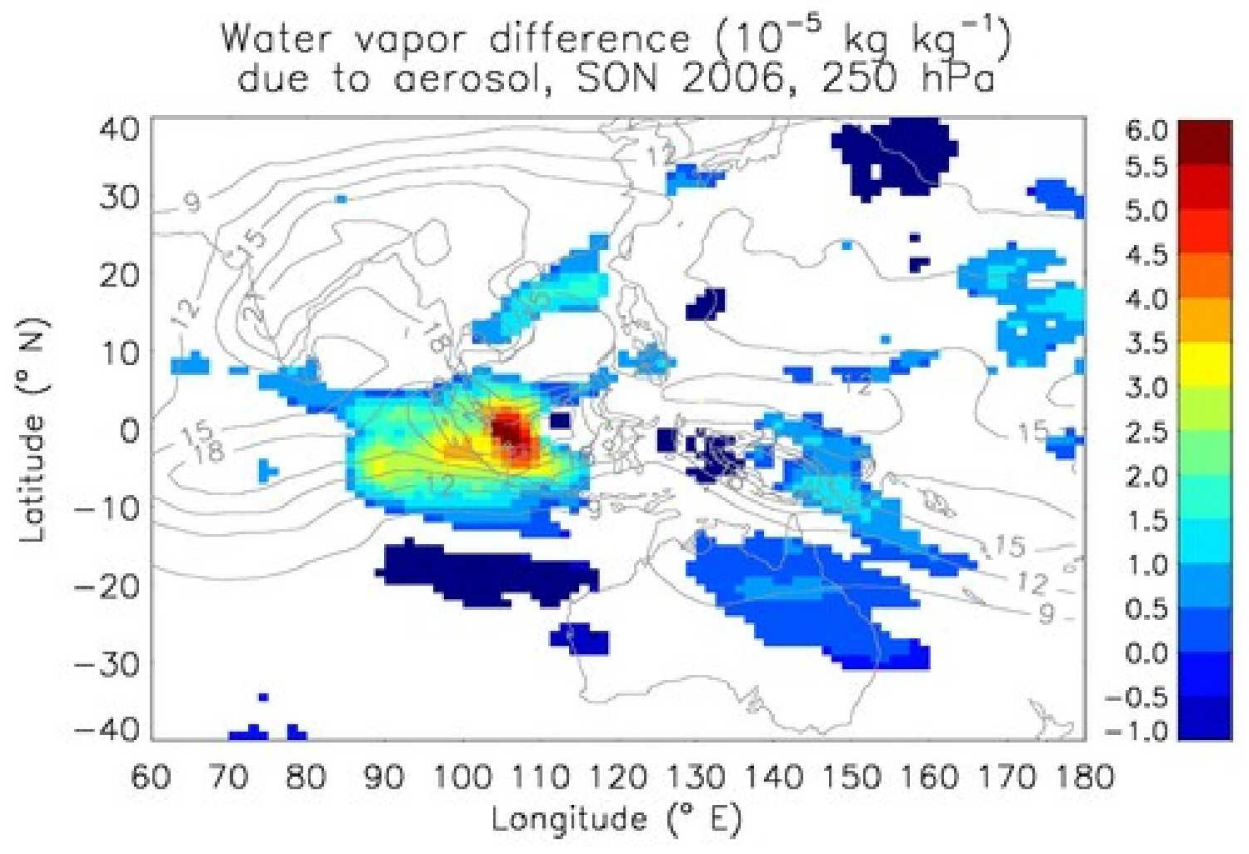

Figure 10. Average specific humidity difference during SON 2006 at $250 \mathrm{hPa}$ resulting from simulating the effects of Indonesian fire aerosols (AERO ensemble mean minus NAERO ensemble mean). Only statistically significant (as indicated by the Student's ttest) grid column differences are shown. Grey contours show AERO ensemble-mean specific humidity. 
(a)

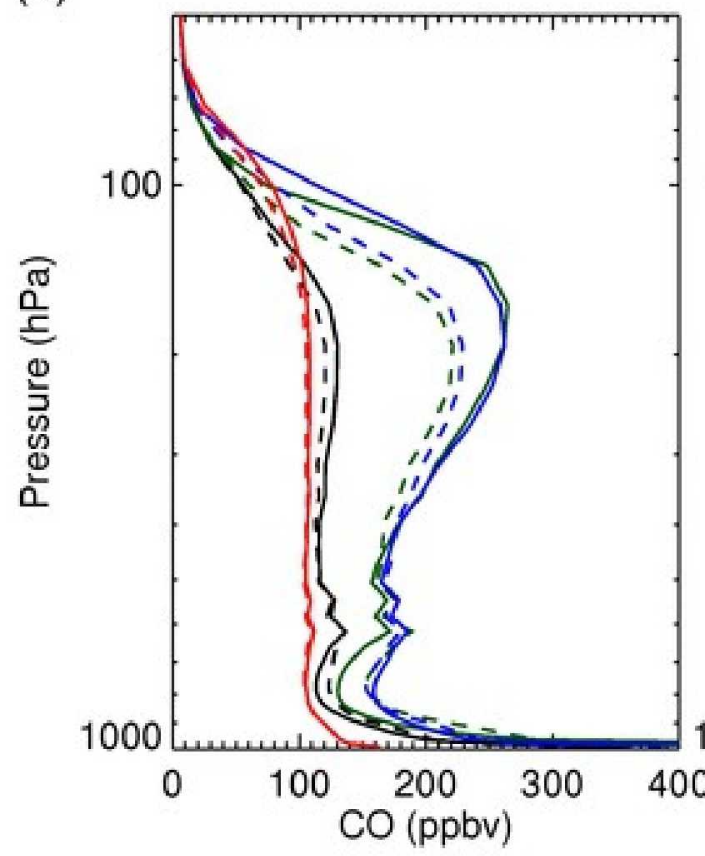

(b)

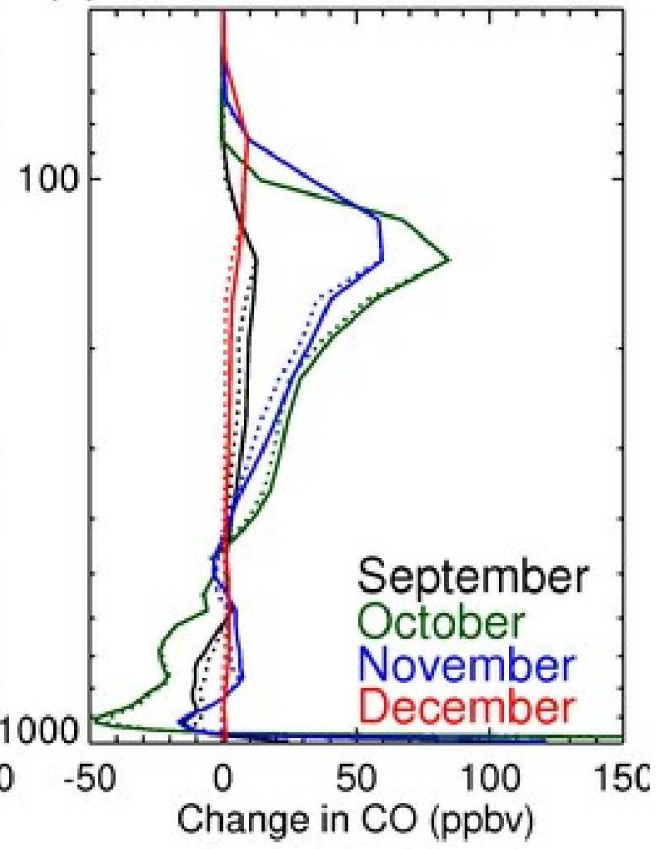

Figure 11. (a) Profiles of $\mathrm{CO}$ from the AERO (solid) and NAERO (dashed) ensembles and (b) changes in CO mixing ratio due to Indonesian aerosols (AERO AERO ensemble mean minus NAERO ensemble mean) in September (black), October (green), November (blue), and December (Red). Solid lines in (b) indicate profiles calculated over all grid cells between $100^{\circ}$ to $120^{\circ} \mathrm{E}$ and $10^{\circ} \mathrm{S}$ to $10^{\circ} \mathrm{N}$ while dotted lines in (b) indicate profiles including only grid cells in which the Student's t-test indicated statistically significant differences. 

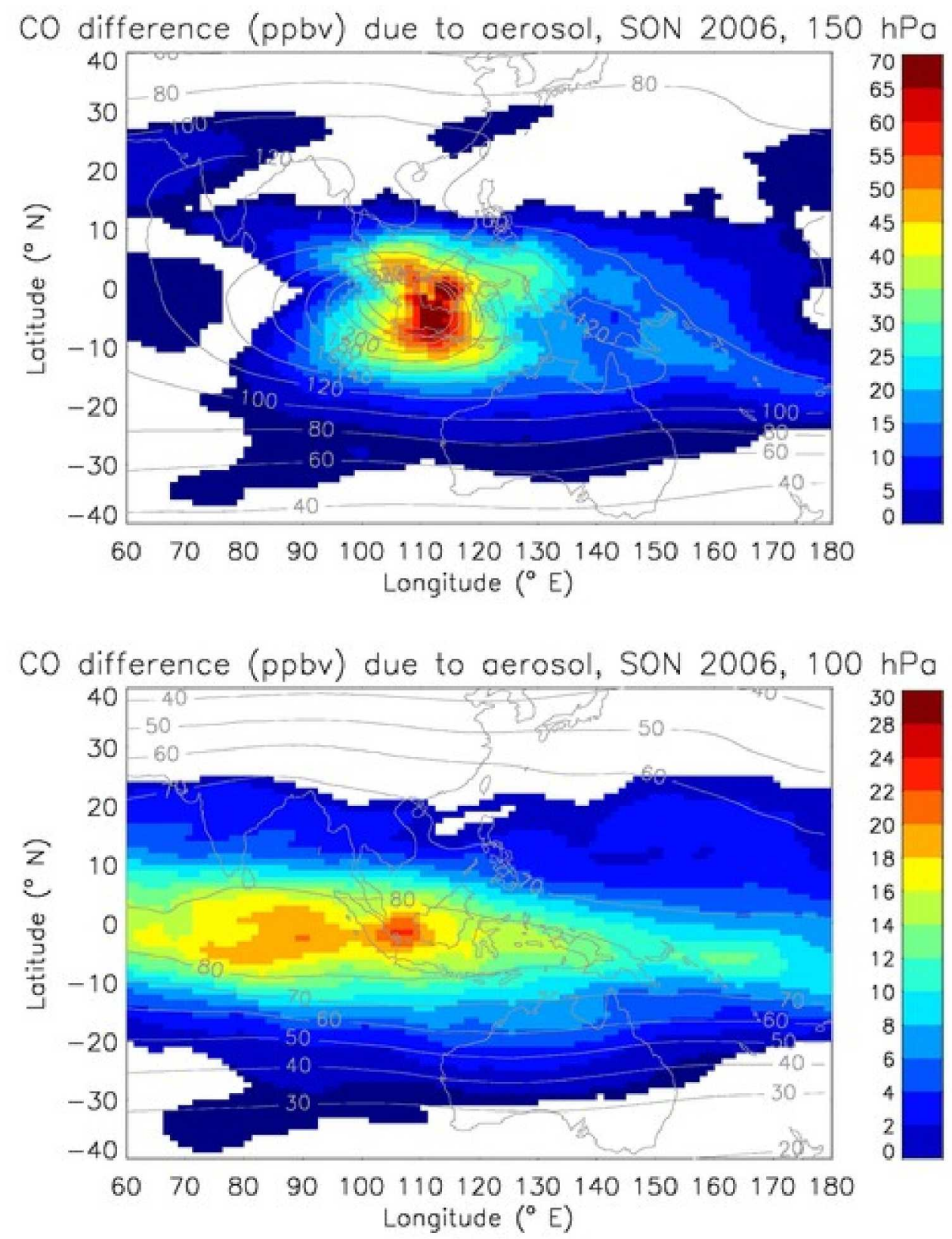

Figure 12. Average CO mixing ratio difference during SON 2006 at $150 \mathrm{hPa}$ (top) and $100 \mathrm{hPa}$ (bottom) resulting from simulating the effects of Indonesian BB aerosols (AERO ensemble mean minus NAERO ensemble mean). Only statistically significant (as indicated by the Student's t-test) grid column differences are shown. Grey contours show AERO ensemble mean $\mathrm{CO}$ mixing ratios. 


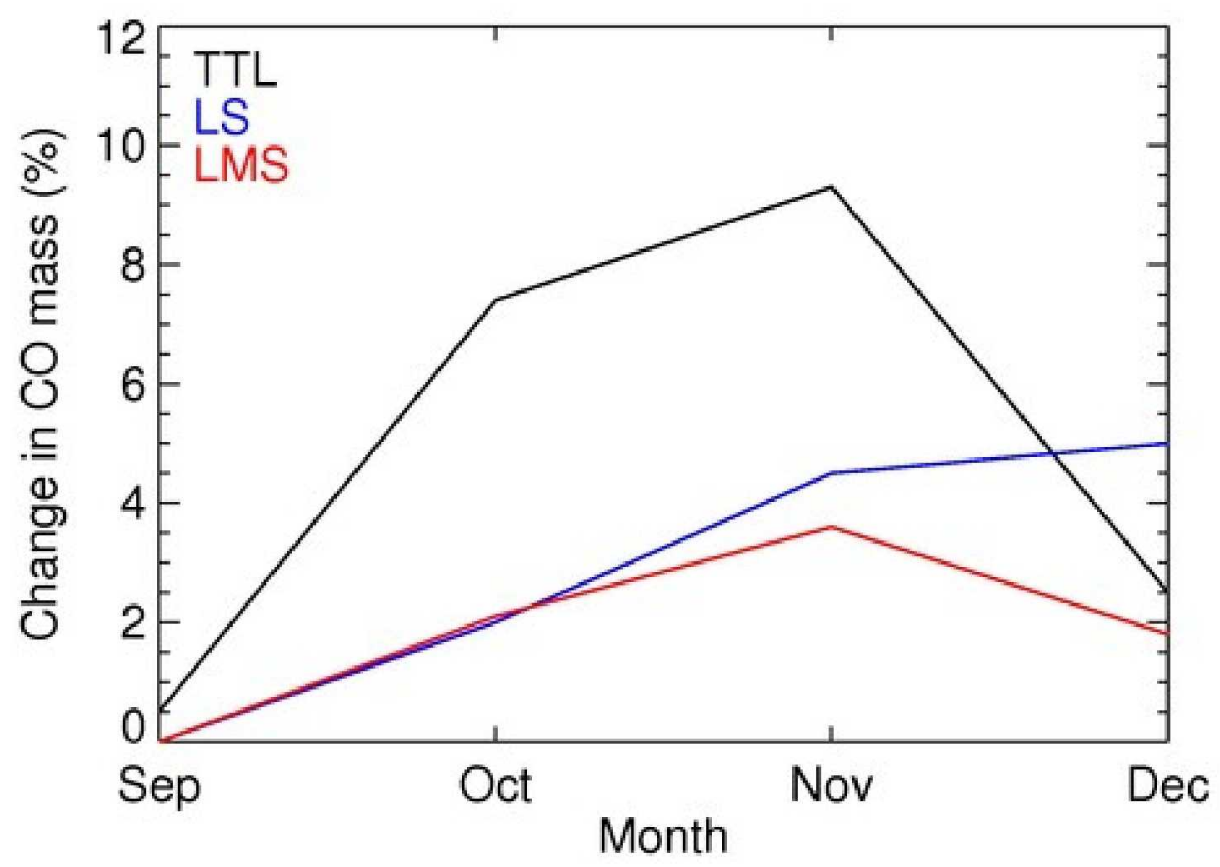

Figure 13. Monthly mass perturbation (AERO ensemble mean minus NAERO ensemble mean) in the TTL (region below the tropopause but above $150 \mathrm{mb}$; black), LS (region above the tropopause but below $60 \mathrm{hPa}$; blue), and lowermost stratosphere (region above the tropopause but with potential temperature less than $380 \mathrm{~K}$; red) caused by Indonesian BB aerosols. 


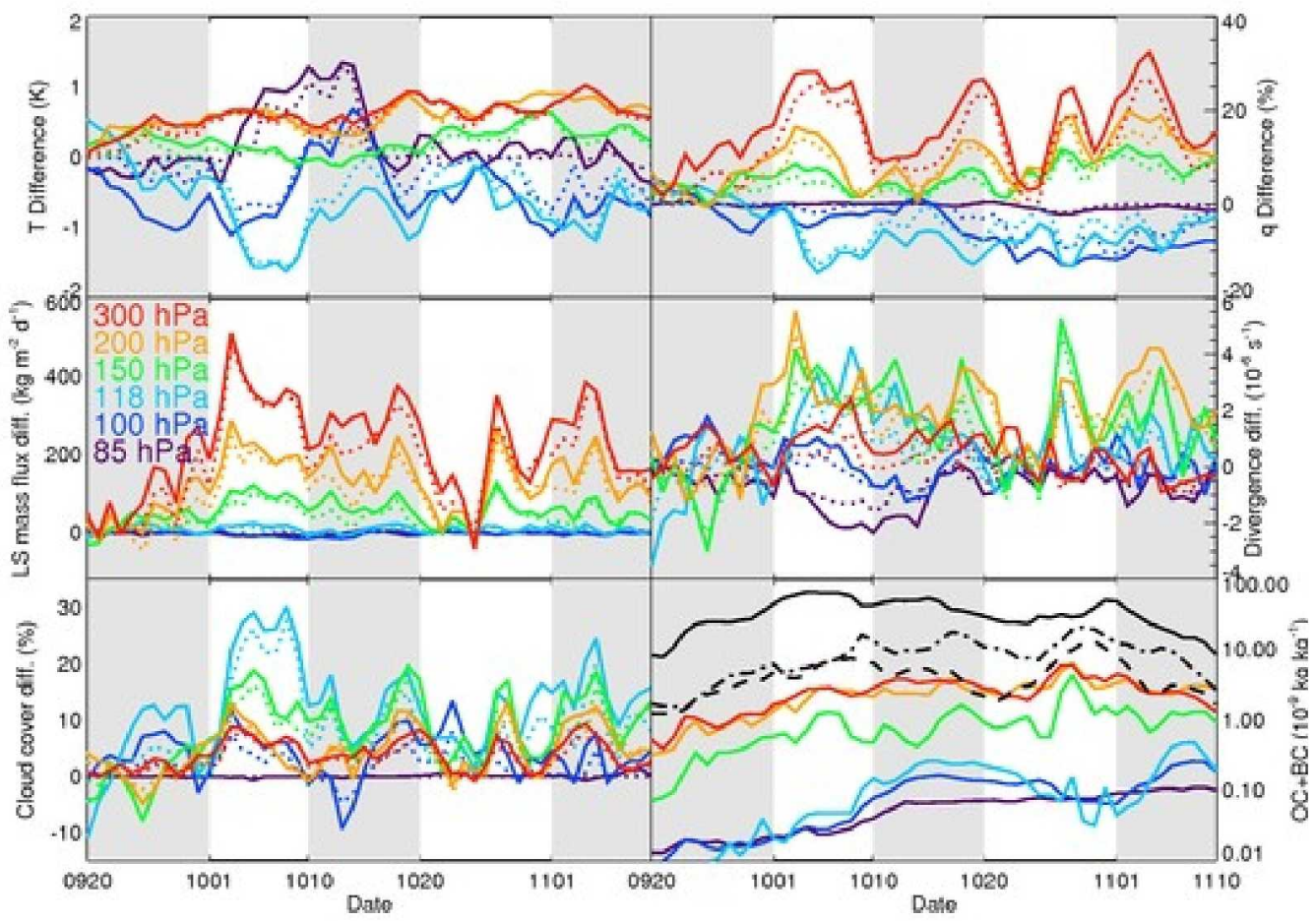

Figure 14. Daily evolution of changes in area mean temperature, specific humidity, gridscale mass flux, horizontal divergence, cloud cover, and carbonaceous aerosol mass mixing ratio caused by Indonesian fires (AERO ensemble mean minus NAERO ensemble mean) at 300 (red), 200 (orange), 150 (green), 118 (light blue), 100 (dark blue), and 85 (purple) hPa. Carbonaceous aerosol plot also includes changes in aerosol mass mixing ratio at 850 (solid black), 700 (dash-dot black), and 500 (dashed black) hPa. Solid lines indicate quantities calculated over all grid cells from $100^{\circ}$ to $120^{\circ} \mathrm{E}$ and $10^{\circ} \mathrm{S}$ to $10^{\circ} \mathrm{N}$ while dotted lines indicate quantities calculated including only grid cells in which the Student's t-test indicated statistically significant differences. 